Article

\title{
Peroxidative Oxidation of Alkanes and Alcohols under Mild Conditions by Di- and Tetranuclear Copper (II) Complexes of Bis (2-Hydroxybenzylidene) Isophthalohydrazide
}

\author{
Manas Sutradhar ${ }^{1, *}$, Elisabete C.B.A. Alegria ${ }^{1,2, *}$, , M. Fátima C. Guedes da Silva ${ }^{1, *(\mathbb{0},}$ \\ Cai-Ming Liu ${ }^{3}$ (i) and Armando J. L. Pombeiro ${ }^{1}$ \\ 1 Centro de Química Estrutural, Instituto Superior Técnico, Universidade de Lisboa, Av. Rovisco Pais, \\ 1049-001 Lisboa, Portugal; pombeiro@tecnico.ulisboa.pt \\ 2 Chemical Engineering Departament, Instituto Superior de Engenharia de Lisboa, \\ Instituto Politécnico de Lisboa, R. Conselheiro Emídio Navarro, 1, 1959-007 Lisboa, Portugal \\ 3 National Laboratory for Molecular Sciences, Center for Molecular Science, Institute of Chemistry, \\ Chinese Academy of Sciences, Beijing 100190, China; cmliu@iccas.ac.cn \\ * Correspondence: manas@tecnico.ulisboa.pt (M.S.); ebastos@deq.isel.ipl.pt (E.C.B.A.A.); \\ fatima.guedes@tecnico.ulisboa.pt (M.F.C.G.d.S.); Tel.: +351-21-841-9237 (M.F.C.G.d.S.)
}

Received: 27 September 2018; Accepted: 15 October 2018; Published: 19 October 2018

check for updates

\begin{abstract}
Bis(2-hydroxybenzylidene)isophthalohydrazide $\left(\mathrm{H}_{4} \mathrm{~L}\right)$ has been used to synthesize the dinuclear $\left[\mathrm{Cu}_{2}\left(1 \kappa N O^{2}: 2 \kappa N^{\prime} O^{\prime 2}-\mathrm{H}_{2} \mathrm{~L}\right)\left(\mathrm{NO}_{3}\right)_{2}\left(\mathrm{H}_{2} \mathrm{O}\right)_{2}\right](\mathbf{1})$ and the tetranuclear $\left[\mathrm{Cu}_{4}\left(\mu-1 \kappa N O^{2}: 2 \kappa N^{\prime} O^{2}-\right.\right.$ $\left.\left.\mathrm{H}_{2} \mathrm{~L}\right)_{2}\left(\mu-\mathrm{NO}_{3}\right)_{2}\left(\mathrm{H}_{2} \mathrm{O}\right)_{4}\right] \cdot 2 \mathrm{C}_{2} \mathrm{H}_{5} \mathrm{OH}(2)$ complexes. The solvent plays an important role in determining the ligand behaviour in the syntheses of the complexes. An ethanol-acetonitrile mixture of solvents favours partials enolization in the case of $\mathbf{2}$. Both complexes have been characterized by elemental analysis, infrared radiation (IR), single crystal X-ray crystallography and electrochemical methods. The variable temperature magnetic susceptibility measurements of $\mathbf{2}$ show strong antiferromagnetic coupling between the central nitrato-bridged $\mathrm{Cu}$ (II) ions. The catalytic activity of both $\mathbf{1}$ and $\mathbf{2}$ has been screened toward the solvent-free microwave-assisted oxidation of alcohols and the peroxidative oxidation of alkanes under mild conditions. Complex 1 exhibits the highest activity for both oxidation reactions, leading selectively to a maximum product yield of 99\% (for the 1-phenylethanol oxidation after $1 \mathrm{~h}$ without any additive) and 13\% (for the cyclohexane oxidation to cyclohexyl hydroperoxide, cyclohexanol and cyclohexanone after $3 \mathrm{~h}$ ).
\end{abstract}

Keywords: $\mathrm{Cu}$ (II) complexes; microwave assisted oxidation of alcohols; oxidation of alkanes; solvent free process; magnetism

\section{Introduction}

The oxidation of alcohols to carbonyl-containing compounds [1-3] is one of the fundamental reactions in organic synthesis $[4,5]$, with a great interest due to the application of carbonyl compounds in research and industrial manufacturing, e.g., in the production of new materials [6] and energy sources [7]. In view of their central role in synthetic chemistry and expected further applications, these reactions continue to attract great attention in order to develop environmentally benign processes [8,9] disclosing new efficient catalysts [10,11], substrates or oxidation agents which could successfully be used in the near future and make a difference in terms of efficiency, selectivity, economy and/or sustainability of the processes. The metal-catalyzed aerobic and peroxidative oxidations of alcohols, in particular of benzylic alcohols, are typical model reactions due to their 
importance and generality; inexpensive primary oxidants such as $\mathrm{O}_{2}, \mathrm{H}_{2} \mathrm{O}_{2}$ or tert-butylhydroperoxide (TBHP) and simple procedures are usually explored [1-5]. The accelerating effect of microwave (MW) irradiation in the synthesis of ketones from secondary alcohols with TBHP as an oxidant has been largely reported [12-18]; this technology is a useful alternative source in organic synthesis, with an environmentally friendly nature.

The mild oxidation of cycloalkanes by hydrogen peroxide to the corresponding alkyl hydroperoxides, alcohols and ketones, a highly significant reaction in terms of industrial interest, remains a challenge in modern catalysis [19-24].

It has been shown that copper (II) complexes are useful catalysts towards the MW assisted oxidation of alcohols and also the functionalization of inert alkanes into valuable organic products, using readily available and cheap oxidants [22,25-28]; however, such applications are still limited and the subject requires further exploration. Moreover, aroylhydrazone complexes are potentially important as oxidation catalyst and some of them also showed interesting magnetic properties [29-32].

Continuing our research on the syntheses of aroylhydrazone metal complexes and their application in catalysis, herein we report the syntheses and characterization of new dinuclear and tetranuclear $\mathrm{Cu}(\mathrm{II})$ complexes derived from the aroylhydrazone Schiff base bis(2-hydroxybenzylidene) isophthalohydrazide $\left(\mathrm{H}_{4} \mathrm{~L}\right)$, their electrochemical behaviour and magnetic properties (2), as well as their catalytic activity in the solvent-free MW assisted peroxidative oxidation of alcohols and also in the oxidation of alkanes under mild conditions, towards the development of environmentally friendly catalytic systems.

\section{Results and Discussion}

\subsection{Syntheses and Characterizations}

The aroylhydrazone Schiff base bis(2-hydroxybenzylidene) isophthalohydrazide $\left(\mathrm{H}_{4} \mathrm{~L}\right)$ has two potential tridentate coordination pockets which can bind two metal centres simultaneously. It has previously been observed [32-34] that the aroylhydrazone can act as ligand in two tautomeric (keto or enol) forms. At room temperature, deprotonation of the phenolic -OH group from the aroylhydrazone in the presence of a copper (II) source, in methanol, generates the $\mathrm{H}_{2} \mathrm{~L}^{2-}$ species and leads to the stable dinuclear complex 1 (Scheme 1). When the reaction is carried out in a 2:1 acetonitrile-ethanol solvent mixture, part of the aroylhydrazone remains in the keto form, the remaining undergoing enolization and deprotonation during complexation. As a result, a $\mathrm{HL}^{3-}$ species is formed in solution and provides the tetranuclear complex $\mathbf{2}$ (Scheme 1). This compound $\mathbf{2}$ can be considered as a dimer of $\mathbf{1}$, where the two central $\mathrm{Cu}$ (II) ions are bridged by two nitrate ions and one of the phenoxido groups of the organic ligand. The IR spectra of complexes 1 and 2 contain all the characteristic bands of the corresponding coordinated tridentate anionic ligand viz., 3476, 3024, 1608, 1254 and $1159 \mathrm{~cm}^{-1}$ for 1 and 3388, 3226, $2978,1611,1252$ and $1068 \mathrm{~cm}^{-1}$ for 2 . The electrospray ionization mass spectrometry (ESI-MS) spectra of both compounds, in ethanol solution (see experimental section), display the molecular ion peaks at $m / z=672[\mathbf{1}+\mathrm{H}]^{+}(100 \%)$ and at $m / z=1158[2+\mathrm{H}]^{+}(100 \%)$. 
<smiles>O=C(N/N=C/c1ccccc1O)c1cccc(C(=O)N/N=C/c2ccccc2O)c1</smiles>

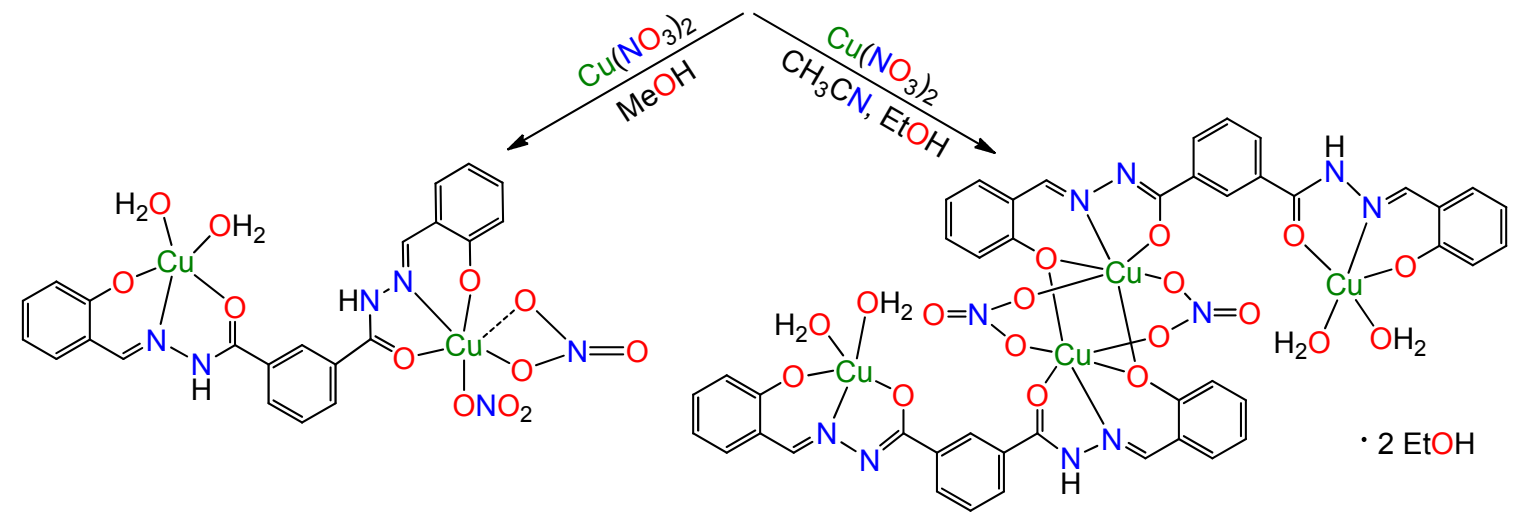

(1)

(2)

Scheme 1. Syntheses of 1 and 2.

\subsection{General Description of the Crystal Structures}

X-ray low quality (low diffracting) crystals of $\mathbf{1}$ and $\mathbf{2}$ were obtained upon slow evaporation of a methanolic (for 1) or an acetonitrile-ethanol solution mixture (for 2), at room temperature. Crystallographic data are summarized in Table 1, representative plots are displayed in Figures 1 and 2, and selected dimensions are presented in Table 2. Cif files for Compound $\mathbf{1}$ and Compound $\mathbf{2}$ are available as Supporting Information for this paper.

The organic ligand in $\mathbf{1}$ and $\mathbf{2}$ is almost planar, behaves as a hexadentate chelator and acts as a $\mathrm{NO}_{2}$ donor for each metal cation in $\mathbf{1}$ and for the outer ones in 2, while for the inner metals it

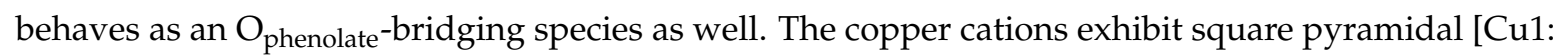
$\tau_{5}=0.08(\mathbf{1})$ and $\left.0.06(2)\right]$, distorted penta-coordinate $\left(\mathrm{Cu} 2\right.$ in $\left.\mathbf{1}, \tau_{5}=0.38\right)$ or distorted octahedral geometries $(\mathrm{Cu} 2$ in 2 ; quadratic elongation $=1.078$, angle variance $=77.60 \stackrel{92}{2}$. The relative orientation of one of the nitrate ligands of $\mathrm{Cu} 1$ in 1 caused a measured $\mathrm{Cu}-\mathrm{O}_{\text {nitrate }}$ bond distance of 2.69(1) $\AA$ which is similar to those of 2.680 (7) and 2.709 (5) $\AA$ in 2, well below the sum on the van der Waals radii of copper and oxygen (1.40 and $1.52 \AA$, respectively). Therefore, on this basis, the geometry of that cation in $\mathbf{1}$ may be thought as octahedral, although with a great distortion (quadratic elongation $=1.125$, angle variance $=272.62^{\stackrel{\circ}{2}}$ ).

Compound $\mathbf{2}$ can be considered as a dimer of $\mathbf{1}$, where dimerization took place at the level of the metals bearing nitrates, leading to a central four-membered dicopper metalacycle. This process affected not only the dimensions involving the central copper cations ( $\mathrm{Cu}_{\text {(nitrate), }}$, see Table 2$)$, but also the outer ones with water ligands bound to copper $\left(\mathrm{Cu}_{\text {(water) }}\right.$, see Table 2), which is probably related to the observed change of geometry (see above the values of $\tau_{5}$ descriptor for such metals). Thus, from 1 to 2, the $\mathrm{Cu}-\mathrm{O}_{\text {phenolate }}$ increased in both types of metals, but the $\mathrm{Cu}-\mathrm{O}_{\text {ketone }}$ increased only in the metal with water ligands, and decreased slightly in the other. Concerning the $\mathrm{Cu}-\mathrm{O}_{\text {water }}$ lengths, they differ markedly in $\mathbf{2}$ with the apical much longer than the equatorial one; in $\mathbf{1}$ the dissimilarity is not so significant, but still the longer distance pertains to the water molecule more distant from the least-square plane of the molecule. An influence has also been perceived in the $\mathrm{Cu}$.. Cu lengths; in the molecule of 2 the distance between the $\mathrm{Cu}_{\text {(nitrate) }}$ and the $\mathrm{Cu}_{\text {(water) }}$ is more than $0.100 \AA$ shorter than in 1, but the shortest intermolecular distance between the metal cations is higher in the former. The effect on selected O-Cu-O and O-Cu-N angles in $\mathbf{1}$ and $\mathbf{2}$ (Table 2) is most probably related to the aforementioned differences in geometry.

Moreover, the enolate forms are more strongly coordinated to the metal centres with shorter $\mathrm{M}-\mathrm{O}$ bond distances than the corresponding ones in the keto forms, as observed in other cases [32-34]. 


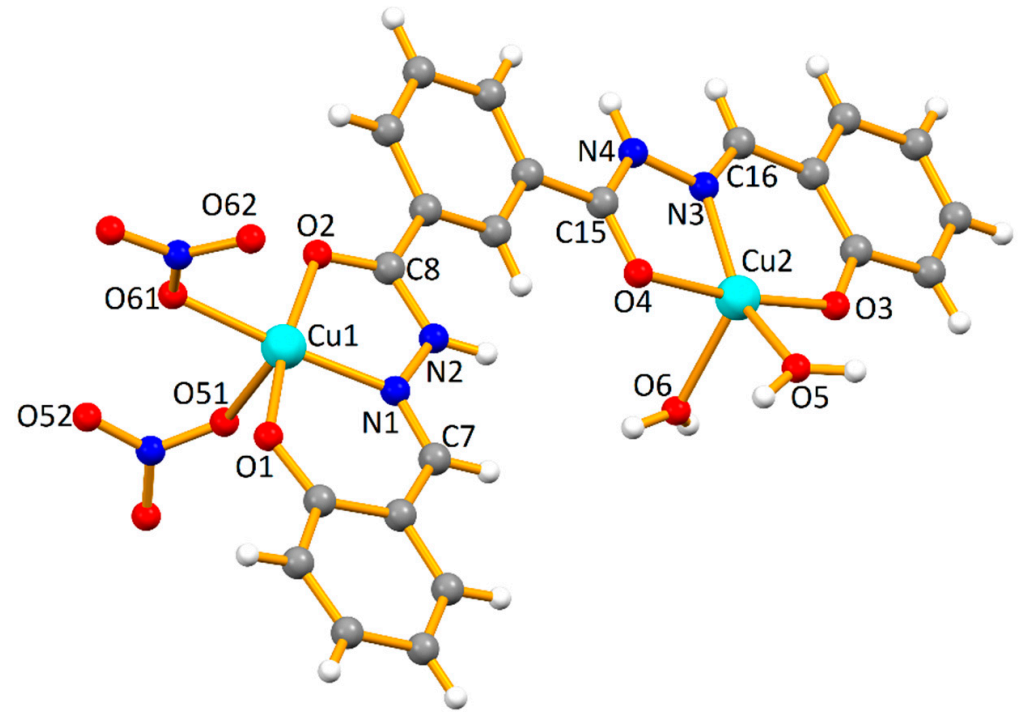

Figure 1. Molecular structure of $\mathbf{1}$ with partial atom numbering scheme. The O-atoms from solvent water molecules are omitted for clarity.

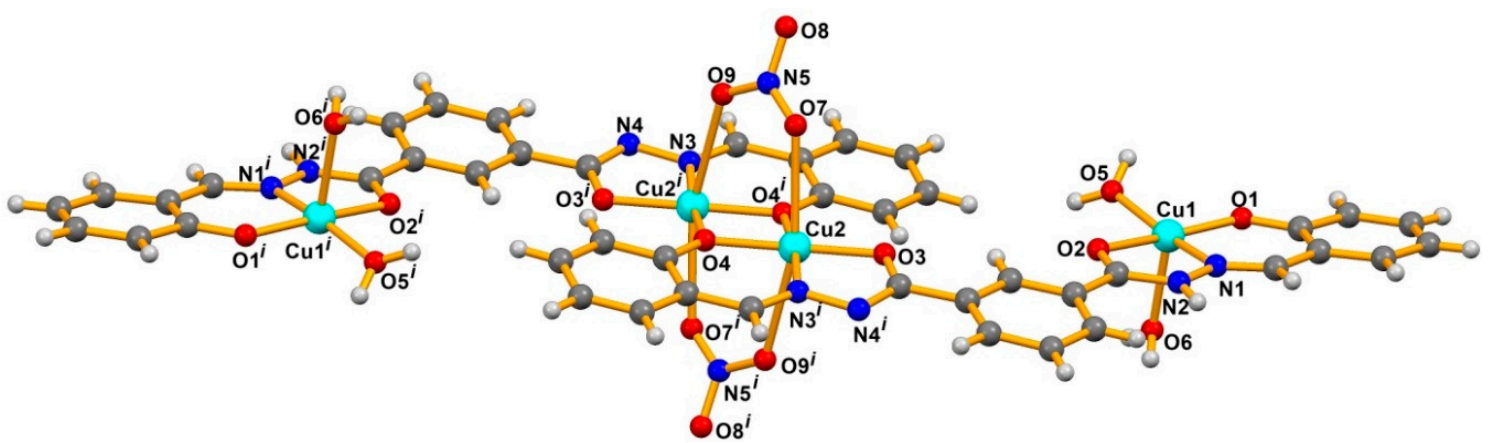

Figure 2. Molecular structure of 2 with partial atom numbering scheme. The ethanol solvent molecule is omitted for clarity. Symmetry operation to generate equivalent atoms (i): $3-x,-y, 1-z$.

Table 1. Crystal data and structure refinement details for complexes $\mathbf{1}$ and $\mathbf{2}$.

\begin{tabular}{ccc}
\hline & $\mathbf{1}$ & $\mathbf{2 \cdot 2 E t O H}$ \\
\hline Empirical formula & $\mathrm{C}_{22} \mathrm{H}_{20} \mathrm{Cu}_{2} \mathrm{~N}_{6} \mathrm{O}_{15}$ & $\mathrm{C}_{48} \mathrm{H}_{50} \mathrm{Cu}_{4} \mathrm{~N}_{10} \mathrm{O}_{20}$ \\
Formula Weight & 735.52 & 1341.14 \\
Crystal system & Triclinic & Triclinic \\
Space group & $P-1$ & $P-1$ \\
Temperature $/ \mathrm{K}$ & $296(2)$ & $296(2)$ \\
$a / \AA$ & $7.8618(4)$ & $9.5722(5)$ \\
$b / \AA$ & $10.1197(6)$ & $10.0444(5)$ \\
$c / \AA$ & $18.1173(10)$ & $14.9699(8)$ \\
$\alpha /{ }^{\circ}$ & $102.605(3)$ & $71.735(2)$ \\
$\beta /{ }^{\circ}$ & $98.203(2)$ & $76.323(3)$ \\
$\gamma /{ }^{\circ}$ & $90.384(3)$ & $80.058(3)$ \\
$V\left(\AA^{3}\right)$ & $1391.19(13)$ & $1320.44(12)$ \\
$Z$ & 2 & 1 \\
$\mathrm{D}_{\text {calc }}\left(\mathrm{g} \mathrm{cm}^{-3}\right)$ & 1.756 & 1.687 \\
$\mu($ Mo K $\alpha)\left(\mathrm{mm}^{-1}\right)$ & 1.615 & 1.677 \\
$R_{\text {int }}$ & $15,443 / 4623 / 2087$ & $17,480 / 4694 / 2675$ \\
Rfls. collected $/$ unique $/$ observed & 0.1339 & 0.0913 \\
Final $R 1^{a}, w^{b}{ }^{b}(I \geq 2 \sigma)$ & $0.0718,0.1441$ & $0.0607,0.1326$ \\
Goodness-of-fit on $F^{2}$ & 0.996 & 1.039 \\
\hline
\end{tabular}

${ }^{a} \mathrm{R}=\Sigma|| F_{o}|-| F_{c}|| / \Sigma\left|F_{o}\right| ;{ }^{b} \mathrm{wR}\left(\mathrm{F}^{2}\right)=\left[\Sigma \mathrm{w}\left(\left|\mathrm{F}_{\mathrm{o}}\right|^{2}-\left|\mathrm{F}_{\mathrm{C}}\right|^{2}\right)^{2} / \Sigma \mathrm{w}\left|\mathrm{F}_{\mathrm{O}}\right|^{4}\right]^{\frac{1}{2}}$. 
Table 2. Selected bond distances $(\AA)$ and angles $\left(^{\circ}\right)$ in complexes 1-2.

\begin{tabular}{|c|c|c|}
\hline Parameter & 1 & 2 \\
\hline $\mathrm{Cu}_{\text {(water) }}-\mathrm{O}_{\text {phenolate }}$ & $1.881(6)$ & $1.903(4)$ \\
\hline $\mathrm{Cu}_{\text {(nitrate) }}-\mathrm{O}_{\text {phenolate }}$ & $1.891(5)$ & $1.925(4)$ \\
\hline $\mathrm{Cu}_{(\text {water })}-\mathrm{O}_{\text {ketone }}$ & $1.964(6)$ & $2.017(4)$ \\
\hline $\mathrm{Cu}_{\text {(nitrate) }}-\mathrm{O}_{\text {ketone }}$ & $1.984(5)$ & $1.919(4)$ \\
\hline $\mathrm{Cu}-\mathrm{O}_{\text {nitrate }}$ & $\begin{array}{c}1.961(7) \\
2.427(7) \\
2.69(1)\end{array}$ & $\begin{array}{l}2.680(7) \\
2.709(5)\end{array}$ \\
\hline & $2.019(8)$ & $1.970(4)$ \\
\hline $\mathrm{Cu}-\mathrm{O}_{\text {water }}$ & $2.131(8)$ & $2.251(5)$ \\
\hline $\mathrm{Cu}-\mathrm{N}$ & $\begin{array}{l}1.935(7) \\
1.938(6)\end{array}$ & $\begin{array}{l}1.905(5) \\
1.933(5)\end{array}$ \\
\hline $\mathrm{N}-\mathrm{N}$ & $\begin{array}{l}1.379(8) \\
1.399(9)\end{array}$ & $\begin{array}{l}1.373(7) \\
1.405(6)\end{array}$ \\
\hline Shortest & & $8.457\left[\mathrm{Cu}_{(\text {water })} \cdots \mathrm{Cu}_{(\text {nitrate })}\right]$ \\
\hline intramolecular $\mathrm{Cu} \cdots \mathrm{Cu}$ & $9.471\left[\mathrm{Cu}_{\text {(water) }} \cdots \mathrm{Cu}_{\text {(nitrate) }}\right]$ & $2.928\left[\mathrm{Cu}_{(\text {nitrate })} \cdots \mathrm{Cu}_{(\text {nitrate })}\right]$ \\
\hline $\begin{array}{c}\text { intermolecular } \mathrm{Cu} \cdots \mathrm{Cu} \\
\text { Largest }\end{array}$ & $5.471\left[\mathrm{Cu}_{(\text {water })} \cdots \mathrm{Cu}_{(\text {nitrate) }}\right]$ & $6.120\left[\mathrm{Cu}_{(\text {water })} \cdots \mathrm{Cu}_{(\text {nitrate })}\right]$ \\
\hline $\mathrm{O}-\mathrm{Cu}_{(\text {water })}-\mathrm{O}$ & $172.3(3)$ & $170.53(18)$ \\
\hline $\mathrm{O}-\mathrm{Cu}_{(\text {water })}-\mathrm{N}$ & 149.8(5) & $167.0(2)$ \\
\hline $\mathrm{O}-\mathrm{Cu}_{(\text {nitrate) }}-\mathrm{O}$ & $171.6(2)$ & $174.01(18)$ \\
\hline $\mathrm{O}-\mathrm{Cu}_{(\text {(nitrate) }}-\mathrm{N}$ & $176.5(3)$ & 170.71(19) \\
\hline
\end{tabular}

\subsection{Electrochemical Properties}

Cyclic voltammograms of $\mathbf{1}$ and $\mathbf{2}$ exhibit a first single-electron (per metal atom) irreversible reduction process (wave $\mathbf{I}^{\text {red }}$ ) at ${ }^{\mathrm{I}} E_{\mathrm{p}}$ red -0.27 or $-0.43 \mathrm{~V}$ vs. SCE, for $\mathbf{1}$ or $\mathbf{2}$, respectively, followed, at a lower potential, by a second single-electron (per metal atom) reduction (wave Ired) at $^{\text {red }}$ ${ }^{\mathrm{II}} E_{\mathrm{p}}{ }^{\text {red }}=-1.12$ or $-1.08 \mathrm{~V}$ vs. SCE, for $\mathbf{1}$ or $\mathbf{2}$, respectively, which are believed to correspond to the $\mathrm{Cu}^{\mathrm{II}} \rightarrow \mathrm{Cu}^{\mathrm{I}}$ (wave $\mathrm{I}^{\text {red }}$ ) and $\mathrm{Cu}^{\mathrm{I}} \rightarrow \mathrm{Cu}^{0}$ (wave $\mathrm{II}^{\text {red }}$ ) cathodic processes, in this order. Upon scan reversal following the first reduction wave, an irreversible oxidation at ${ }^{\mathrm{I}} E_{\mathrm{p}}{ }^{\text {ox }}-0.05$ or $0.02 \mathrm{~V}$ vs. $\mathrm{SCE}$, for $\mathbf{1}$ or $\mathbf{2}$, respectively, was detected and assigned to the oxidation of a novel $\mathrm{Cu}(\mathrm{I})$ species. By reversing the direction of the potential scan after the formation of wave $\mathbf{I I}^{\text {red }}$, an adsorption wave was formed at ${ }^{\mathrm{II}} E_{\mathrm{p}}{ }^{\text {ox }} 0.15$ or $0.27 \mathrm{~V}$ vs. SCE for $\mathbf{1}$ or $\mathbf{2}$, respectively.

Expectedly, no genuine anodic waves have been detected for any of the complexes. Bis(2-hydroxybenzylidene) isophthalohydrazide $\left(\mathrm{H}_{4} \mathrm{~L}\right)$ was not redox active under our experimental conditions, and hence the cyclic voltammetric waves of $\mathbf{1}$ and $\mathbf{2}$ can be due to metal-based electron transfer processes.

\subsection{Magnetic Properties}

The dc magnetic susceptibilities of complex 2 have been determined under 2000 Oe from $2 \mathrm{~K}$ to $300 \mathrm{~K}$. As shown in Figure 3, the $\chi_{\mathrm{M}} T$ value at $300 \mathrm{~K}$ is $1.48 \mathrm{~cm}^{3} \mathrm{~K} \mathrm{~mol}^{-1}$, slightly smaller than the expected value for four noninteracting $\mathrm{Cu}^{2+}$ ions $(g=2.0)$. The $\chi_{\mathrm{M}} T$ product decreases with the decreased temperture until about $100 \mathrm{~K}$, then drops slowly to about $10 \mathrm{~K}$; below this temperature, $\chi_{\mathrm{M}} T$ further decreases. These results indicate that there are antiferromagnetic interactions between copper(II) ions.

A linear tetranuclear copper (II) magnetic coupling model was adopted to analyze the magnetic interaction [35]. Owing to the crystallographic inversion symmetry, four exchange coupling constants $J_{1}, J_{2}, J_{3}$ and $J_{4}$ were used in the Hamiltonian, $H=-2 J_{1}\left(\mathrm{~S}_{1} \mathrm{~S}_{2}+\mathrm{S}_{1^{\prime}} \mathrm{S}_{2^{\prime}}\right)-2 J_{2} \mathrm{~S}_{2} \mathrm{~S}_{2^{\prime}}-2 J_{3}\left(\mathrm{~S}_{1} \mathrm{~S}_{2^{\prime}}+\mathrm{S}_{1^{\prime}} \mathrm{S}_{2}\right)$ $-2 J_{4}\left(\mathrm{~S}_{1} \mathrm{~S}_{1^{\prime}}\right)$ [35]; they represent the magnetic interactions between $\mathrm{Cu} 1$ and $\mathrm{Cu} 2$ (or $\mathrm{Cu} 1^{\mathrm{i}}$ and $\mathrm{Cu} 2^{\mathrm{i}}$ ), $\mathrm{Cu} 2$ and $\mathrm{Cu} 2^{\mathrm{i}}, \mathrm{Cu} 1$ and $\mathrm{Cu} 2^{\mathrm{i}}$ (or $\mathrm{Cu} 1^{\mathrm{i}}$ and $\mathrm{Cu} 2$ ), and between $\mathrm{Cu} 1$ and $\mathrm{Cu} 1^{\mathrm{i}}$, respectively. Given the high number of variables, fitting the magnetic data using all four coupling constants led to unreasonable results. Since the distance between $\mathrm{Cu} 1$ and $\mathrm{Cu}{ }^{\mathrm{i}}$ (or $\mathrm{Cu} 1^{\mathrm{i}}$ and $\mathrm{Cu} 2$ ) and the distance 
between $\mathrm{Cu} 1$ and $\mathrm{Cu} 1^{\mathrm{i}}$ are large enough, $J_{3}$ and $J_{4}$ could be considered as zero for a simplified model, and better results were thus achieved. The best fitting gave $g=2.02, J_{1}=-5.1 \mathrm{~cm}^{-1}, J_{2}=-172.8 \mathrm{~cm}^{-1}$ and $N \alpha=4.8 \times 10^{-5}$ with $R=5.5 \times 10^{-4}\left(R=\Sigma\left[\left(\chi_{\mathrm{M}}\right)_{\text {obs }}-\left(\chi_{\mathrm{M}}\right)_{\mathrm{calc}}\right]^{2} / \Sigma\left[\left(\chi_{\mathrm{M}}\right)_{\mathrm{obs}}\right]^{2}\right)$. The large negative value of $J_{2}$ reveals that there is a strong antiferromagnetic exchange between the $\mathrm{Cu}$ (II) ions mediated by the $\mathrm{O}_{\text {phenolate }}$ and $\mathrm{NO}_{3}{ }^{-}$bridges.

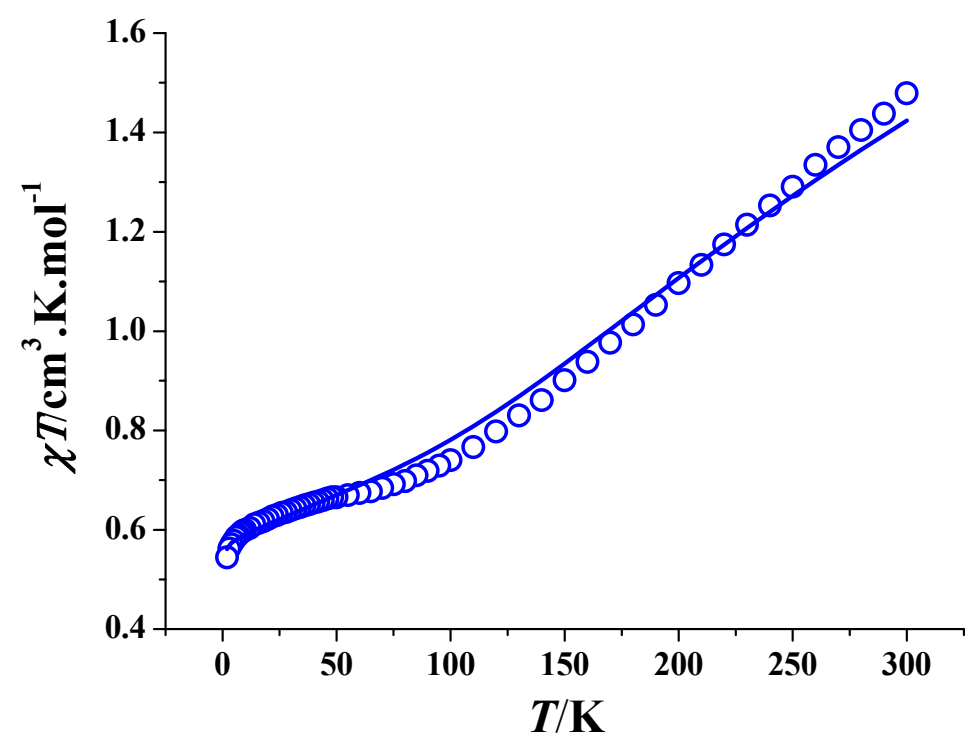

Figure 3. Plot of $\chi_{M} \mathrm{~T}$ versus $\mathrm{T}$ for complex 2. The solid line represents the best theoretical fitting.

\subsection{Catalytic Studies}

\subsubsection{Solvent-Free Microwave (MW) Assisted Oxidation of Secondary Alcohols}

Complexes 1 and 2 were tested as catalyst precursors for the homogeneous oxidation of secondary alcohols [1-phenylethanol (model substrate), cyclohexanol, 2-hexanol and 3-hexanol] to the corresponding ketones following our previously developed procedure [18,31,36-39] using tert-butylhydroperoxide ( $t$-BuOOH, Equation (2), used as aq. $70 \%)$ as oxidizing agent, under typical conditions of $80-120^{\circ} \mathrm{C}$, microwave (MW) irradiation (5-20 W), 0.5-3 h reaction time and in the absence of any added solvent (Scheme 2 for 1-phenylethanol and cyclohexanol oxidation). Results are summarized in Tables 3 and 4 .

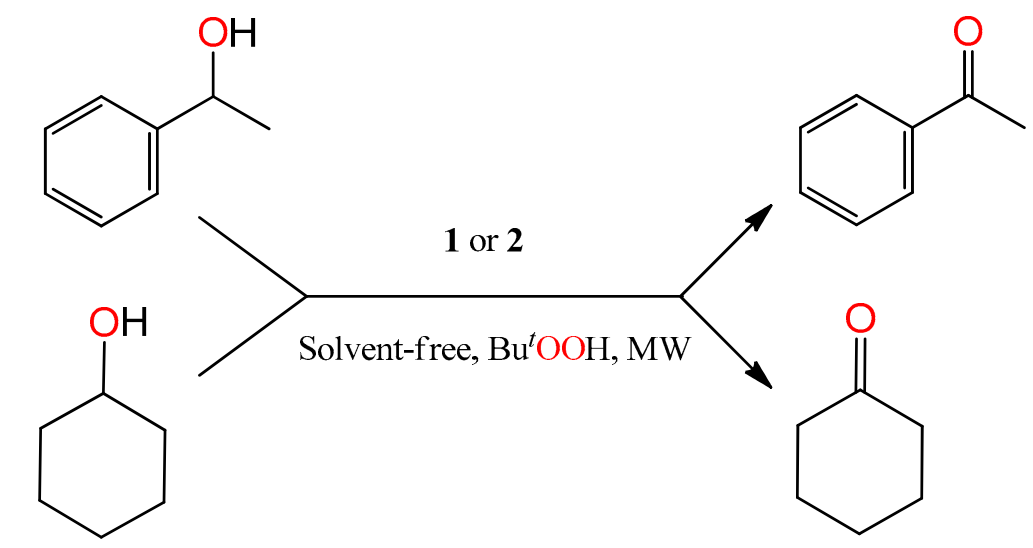

Scheme 2. Microwave (MW)-assisted solvent-free oxidation of 1-phenylethanol and cyclohexanol to acetophenone and cyclohexanone, respectively, catalysed by $\mathbf{1}$ or $\mathbf{2}$. 
Under typical reaction conditions $\left(120{ }^{\circ} \mathrm{C}\right.$ and $0.5 \mathrm{~h}$ reaction time) ketone yields up to $37 \%$ $\left(\mathrm{TOF}=264 \mathrm{~h}^{-1}\right)$ are obtained for the oxidation of 1-phenylethanol (Table 3, entry 3) by the 1/TBHP/MW system (catalyst/substrate molar ratio of $0.2 \%$ ) and in the absence of any additive. For a longer reaction time of 1 and $3 \mathrm{~h}$, and for the same catalytic system, the oxidation by TBHP of 1-phenyletanol leads to 75 and $95 \%$ of acetophenone, respectively (Table 3, entries 4 and 5). The acetophenone yield value for $1 \mathrm{~h}$ reaction (Table 3, entry 4) is significantly higher than that obtained (17\%, Table 3, entry 15) without MW assistance, for the same reaction time. Reactions performed at $120{ }^{\circ} \mathrm{C}$ with $20 \mathrm{~W}$ of MW irradiation and in the presence of complex 2 (2/TBHP/MW) resulted only in 28,42 and $71 \%$ of acetophenone after $0.5,1$ and 3 h of oxidation reaction, respectively (Table 3, entries 16-18, respectively). The addition of the heteroaromatic 2-pyrazynecarboxylic acid (Hpca) or of trifluoroacetic acid (TFA) to the $1 / \mathrm{TBHP} / \mathrm{MW}$ system [ $n$ (acid) $/ n$ (catalyst 1 ) $=10$ ], slightly improved the yield from 11 to $14 \%$ (Table 3, entry 6 ) or to $18 \%$ (Table 3 , entry 9 ), respectively, when the reaction was performed at $80{ }^{\circ} \mathrm{C}$ for $0.5 \mathrm{~h}$.

A major effect was observed in the presence of 2,2,6,6-tetramethylpiperydil-1-oxyl (TEMPO) radical, an efficient promotor in aerobic oxidation of alcohols [11,40-48]. In fact, the oxidation of 1-phenylethanol by the 1/TBHP/TEMPO/MW system afforded substantial increase in the yield of acetophenone achieving $99 \%$ after $1 \mathrm{~h}$ at $120{ }^{\circ} \mathrm{C}$ (Table 3, entry 14) or $88 \%$ in only $0.5 \mathrm{~h}$ (Table 3, entry 13). Under the oxidation conditions used, the TEMPO additive could be oxidized to the oxoammonium species acting as oxidant, as well as acting as a hydrogen atom abstract from TBHP, enhancing the formation of tert-BuOO${ }^{\bullet}$ and $t$ - $\mathrm{BuO}^{\bullet}$ [40-48]. The 2/TBHP/TEMPO/MW system was not so effective (Table 3, entries 23 and 24). The blank tests in the absence of metal catalyst (with and without TEMPO) lead to very low conversion (up to $4 \%$ yield) of 1-phenylethanol to acetophenone (Table 3, entries 25 and 26).

Attempts to perform microwave-assisted oxidation of secondary alcohols in the presence of $\mathbf{1}$ or $\mathbf{2}$, in the absence of any additive and at room temperature, failed. Performing the reaction at $80{ }^{\circ} \mathrm{C}$ did not allow yields beyond $27 \%$ in $3 \mathrm{~h}$ (with catalyst 1), but at $120{ }^{\circ} \mathrm{C}$ the product was obtained in 95 (with 1) or $71 \%$ yield (with 2), in the same reaction time (Table 3, entries 5 and 20). The accelerating effect of the increase in temperature was also observed in the presence of the tested additives (Figure 4). Thus, for example, in the presence of the TEMPO radical, one observes a change in the conversion of 1-phenylethanol from 22 to $88 \%$ and in the TOF value from 168 to $1112 \mathrm{~h}^{-1}$ (Table 3 , entries 12 and 13) when going from 80 or $120^{\circ} \mathrm{C}$, in $0.5 \mathrm{~h}$. This feature also concerns the microwave power since at $80{ }^{\circ} \mathrm{C}$ the power went up to $10 \mathrm{~W}$ in the first $10 \mathrm{~s}$ but then, after reaching the desired temperature, it stabilized at ca. $5 \mathrm{~W}$, while for the temperature of $120^{\circ} \mathrm{C}$, ca. $40 \mathrm{~W}$ were reached in the first $10 \mathrm{~s}$ followed by stabilisation at $10-15 \mathrm{~W}$ for the remaining time.

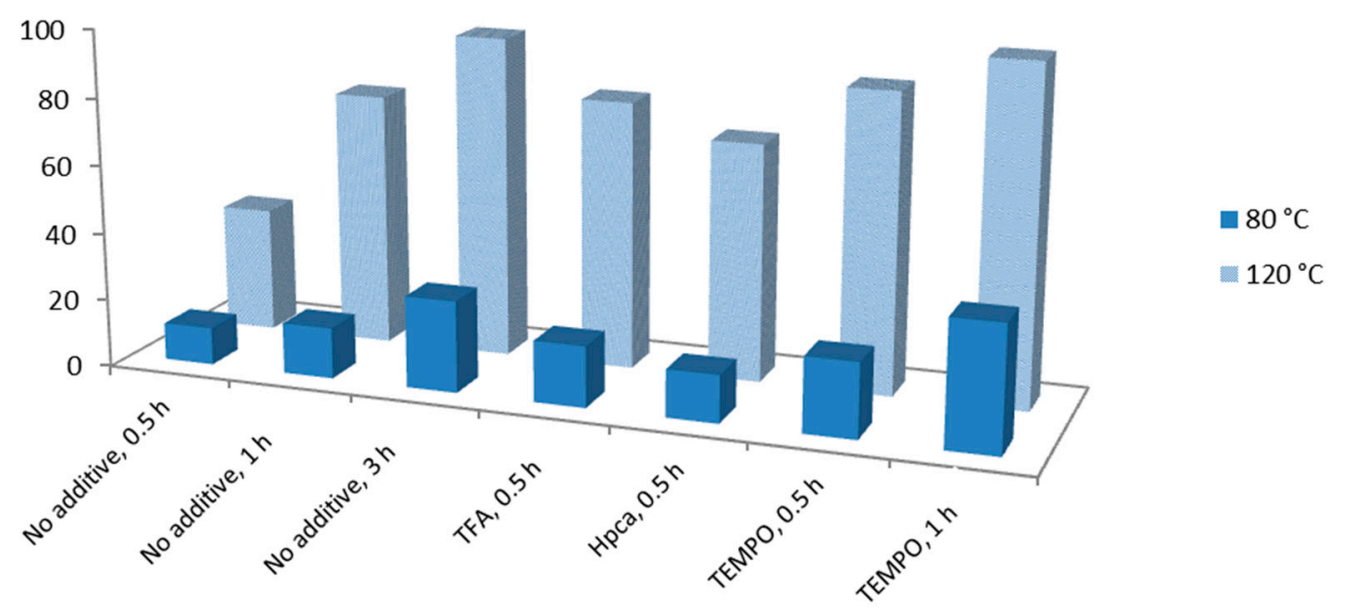

Figure 4. Temperature effect on the yield of acetophenone from MW-assisted peroxidative oxidation of 1-phenylethanol by the 1/TBHP/MW catalytic system. 
Table 3. Selected results for the MW-assisted oxidation of 1-phenylethanol by tert-butylhydroperoxide (TBHP) with 1 and 2 as catalyst precursors ${ }^{a}$.

\begin{tabular}{|c|c|c|c|c|c|c|}
\hline Entry & $\begin{array}{l}\text { Catalyst } \\
\text { Precursor }\end{array}$ & $\begin{array}{l}\text { Reaction Time } \\
\text { (h) }\end{array}$ & $\begin{array}{c}\text { Temperature } \\
\left({ }^{\circ} \mathrm{C}\right)\end{array}$ & $\begin{array}{l}\text { Additive } \\
(\mu \mathrm{mol})\end{array}$ & $\begin{array}{c}\text { Yield }^{b} \\
(\%)\end{array}$ & $\begin{array}{l}\mathrm{TOF}^{c} \\
\left(\mathbf{h}^{-1}\right)\end{array}$ \\
\hline 1 & \multirow{16}{*}{1} & 0.5 & 80 & - & 11 & 108 \\
\hline 2 & & 3 & 80 & - & 27 & 74 \\
\hline 3 & & 0.5 & 120 & - & 37 & 264 \\
\hline 4 & & 1 & 120 & - & 75 & 494 \\
\hline 5 & & 3 & 120 & - & 95 & 222 \\
\hline 6 & & 0.5 & 80 & Нpса (50) & 14 & 118 \\
\hline 7 & & 0.5 & 120 & Hрса (50) & 70 & 538 \\
\hline 8 & & 0.5 & 80 & Hpca (100) & 5 & 64 \\
\hline 9 & & 0.5 & 80 & TFA (50) & 18 & 182 \\
\hline 10 & & 0.5 & 120 & TFA (50) & 79 & 501 \\
\hline 11 & & 0.5 & 80 & TFA (100) & 6 & 89 \\
\hline 12 & & 0.5 & 80 & TEMPO (30) & 22 & 168 \\
\hline 13 & & 0.5 & 120 & TEMPO (30) & 88 & 1112 \\
\hline 14 & & 1 & 120 & TEMPO (30) & 99 & 755 \\
\hline $15^{d}$ & & 1 & 120 & - & 17 & 111 \\
\hline 16 & & 3 & 120 & - & 42 & 98 \\
\hline 17 & \multirow{8}{*}{2} & 0.5 & 80 & - & 5 & 56 \\
\hline 18 & & 0.5 & 120 & - & 28 & 182 \\
\hline 19 & & 1 & 120 & - & 42 & 212 \\
\hline 20 & & 3 & 120 & - & 71 & 137 \\
\hline 21 & & 0.5 & 80 & TFA (50) & 8 & 82 \\
\hline 22 & & 0.5 & 80 & Нpca (50) & 6 & 67 \\
\hline 23 & & 0.5 & 80 & TEMPO (30) & 10 & 78 \\
\hline 24 & & 0.5 & 120 & TEMPO (30) & 46 & 237 \\
\hline 25 & None & 1 & 120 & - & 1 & 6 \\
\hline 26 & None & 1 & 120 & TEMPO & 4 & 21 \\
\hline
\end{tabular}

${ }^{a}$ Reaction conditions (unless stated otherwise): $2.5 \mathrm{mmol}$ of substrate, $5 \mu \mathrm{mol}$ of $\mathbf{1}$ or 2 ( $0.2 \mathrm{~mol} \%$ vs. substrate), $5 \mathrm{mmol}$ of $t$ - $\mathrm{BuOOH}$ (aq. $70 \%$ ), 80 or $120^{\circ} \mathrm{C}$, microwave irradiation (5-20 W). ${ }^{b}$ Molar yield (\%) based on substrate, i.e., moles of product per $100 \mathrm{~mol}$ of substrate determined by G.C. ${ }^{c}$ Turnover frequency $=$ number of moles of product per mol of metal catalyst per hour (turnover number per hour). ${ }^{d}$ Under conventional heating.

Complexes 1 and 2 were also tested towards the oxidation of aliphatic alcohols, namely cyclohexanol and the linear 2- and 3-hexanols. As expected, they were less reactive than 1-phenylethanol (benzylic alcohol derivative), leading to moderate yields in the $15-31 \%$ range (in $0.5 \mathrm{~h}$ reaction at $120^{\circ} \mathrm{C}$, without any additive (Table 4 , entries $1,4,7,10,13$ and 16). The efficiency of the oxidation of those alcohols could also be enhanced by using TEMPO radical and the yields increased to $29-58 \%$ in $0.5 \mathrm{~h}$ (Table 4, entries 2, 5, 8, 11, 14 and 17). Extending the reaction time to $1 \mathrm{~h}$ and in the presence of the same promoter, the conversions raised to $87 \%$ for cyclohexanol (Table 4, entry 3), 71\% for 2-hexanol (Table 4, entry 6) and 59\% for 3-hexanol (Table 4, entry 9) with 1 as catalyst. The position (2 or 3 ) of the $\mathrm{OH}$ group in the aliphatic chain of the linear alcohols (2-hexanol and 3-hexanol) appeared not to influence significantly the efficiency of the system, in view of the obtained yields (compare, e.g., entries 4 and 7 or 6 and 9, Table 4, for complex 1). Blank tests were performed for all aliphatic alcohols in the absence of any catalyst and residual conversions (up to $5 \%$ ) were recorded. 
Table 4. MW-assisted oxidation of selected alcohols by TBHP with $\mathbf{1}$ and $\mathbf{2}$ as catalyst precursors ${ }^{a}$.

\begin{tabular}{|c|c|c|c|c|c|c|}
\hline Entry & $\begin{array}{l}\text { Catalyst } \\
\text { Precursor }\end{array}$ & Substrate & $\begin{array}{l}\text { Reaction } \\
\text { Time (h) }\end{array}$ & $\begin{array}{l}\text { Additive } \\
(\mu \mathrm{mol})\end{array}$ & Yield $^{b}(\%)$ & $\operatorname{TOF}^{c}\left(h^{-1}\right)$ \\
\hline 1 & \multirow{9}{*}{1} & \multirow{3}{*}{ cyclohexanol } & 0.5 & - & 31 & 380 \\
\hline 2 & & & 0.5 & TEMPO (30) & 58 & 568 \\
\hline 3 & & & 1 & TEMPO (30) & 87 & 471 \\
\hline 4 & & \multirow{3}{*}{ 2-hexanol } & 0.5 & - & 21 & 204 \\
\hline 5 & & & 0.5 & TEMPO (30) & 45 & 426 \\
\hline 6 & & & 1 & TEMPO (30) & 71 & 726 \\
\hline 7 & & \multirow{3}{*}{ 3-hexanol } & 0.5 & - & 20 & 194 \\
\hline 8 & & & 0.5 & TEMPO (30) & 43 & 398 \\
\hline 9 & & & 1 & TEMPO (30) & 69 & 321 \\
\hline 10 & \multirow{9}{*}{2} & \multirow{3}{*}{ cyclohexanol } & 0.5 & - & 22 & 222 \\
\hline 11 & & & 0.5 & TEMPO (30) & 34 & 382 \\
\hline 12 & & & 1 & TEMPO (30) & 59 & 285 \\
\hline 13 & & \multirow{3}{*}{ 2-hexanol } & 0.5 & - & 17 & 176 \\
\hline 14 & & & 0.5 & TEMPO (30) & 31 & 368 \\
\hline 15 & & & 1 & TEMPO (30) & 49 & 225 \\
\hline 16 & & \multirow{3}{*}{ 3-hexanol } & 0.5 & - & 15 & 168 \\
\hline 17 & & & 0.5 & TEMPO (30) & 29 & 358 \\
\hline 18 & & & 1 & TEMPO (30) & 51 & 255 \\
\hline
\end{tabular}

${ }^{a}$ Reaction conditions (unless stated otherwise): $2.5 \mathrm{mmol}$ of substrate, $5 \mu \mathrm{mol}$ of $\mathbf{1}$ or $\mathbf{2}(0.2 \mathrm{~mol} \%$ vs. substrate), $5 \mathrm{mmol}$ of $t$ - $\mathrm{BuOOH}$ (aq. $70 \%$ ), $120^{\circ} \mathrm{C}$, microwave irradiation ( $20 \mathrm{~W}$ power). ${ }^{b}$ Molar yield (\%) based on substrate, i.e., moles of product per $100 \mathrm{~mol}$ of substrate determined by GC. ${ }^{c}$ Turnover frequency $=$ number of moles of product per mol of metal catalyst per hour (turnover number per hour).

The catalytic mechanism may proceed through the metal-assisted generation of $t$-BuOO$\bullet$ and $t$ - $\mathrm{BuO} \bullet$ radicals [40-48], upon oxidation or reduction of $t-\mathrm{BuOOH}$ by a $\mathrm{Cu}^{\mathrm{II}}$ or $\mathrm{Cu}^{\mathrm{I}}$ centre (Equations (1) and (2)), respectively, and is summed up in Equations (1)-(6).

$$
\begin{gathered}
\mathrm{Cu}(\mathrm{II})+t-\mathrm{BuOOH} \rightarrow \mathrm{Cu}(\mathrm{I})+t-\mathrm{BuOO}^{\bullet}+\mathrm{H}^{+} \\
\mathrm{Cu}(\mathrm{I})+t-\mathrm{BuOOH} \rightarrow \mathrm{Cu}(\mathrm{II})-\mathrm{OH}+t-\mathrm{BuO}^{\bullet} \\
\mathrm{Cu}(\mathrm{II})-\mathrm{OH}+t-\mathrm{BuOOH} \rightarrow \mathrm{Cu}(\mathrm{II})-\mathrm{OO}-t-\mathrm{Bu}+\mathrm{H}_{2} \mathrm{O} \\
t-\mathrm{BuO}^{\bullet}+\mathrm{R}_{2} \mathrm{CHOH} \rightarrow t-\mathrm{BuOH}+\mathrm{R}_{2} \mathrm{C}^{\bullet}-\mathrm{OH} \\
t-\mathrm{BuOO}{ }^{\bullet}+\mathrm{R}_{2} \mathrm{CHOH} \rightarrow t-\mathrm{BuOOH}+\mathrm{R}_{2} \mathrm{C}^{\bullet}-\mathrm{OH} \\
\mathrm{Cu}(\mathrm{II})-\mathrm{OO}-t-\mathrm{Bu}+\mathrm{R}_{2} \mathrm{C}^{\bullet}-\mathrm{OH} \rightarrow \mathrm{R}_{2} \mathrm{C}=\mathrm{O}+t-\mathrm{BuOOH}+\mathrm{Cu}(\mathrm{I})
\end{gathered}
$$

\subsubsection{Peroxidative Oxidation of Cyclohexane}

Compounds 1 and 2 were also tested as catalyst precursors in the oxidation of cyclohexane by $\mathrm{H}_{2} \mathrm{O}_{2}$ (Equation (2), used as $50 \%$ aqueous solution) at $50{ }^{\circ} \mathrm{C}$ in $\mathrm{MeCN} / \mathrm{H}_{2} \mathrm{O}$ medium (Scheme 3). The reaction was monitored by Gas Chromatography (GC) to determine the amount of cyclohexanol and cyclohexanone formed, typically after treatment with $\mathrm{PPh}_{3}$ (to reduce cyclohexyl hydroperoxide to cyclohexanol) $[29,30,49-51]$.

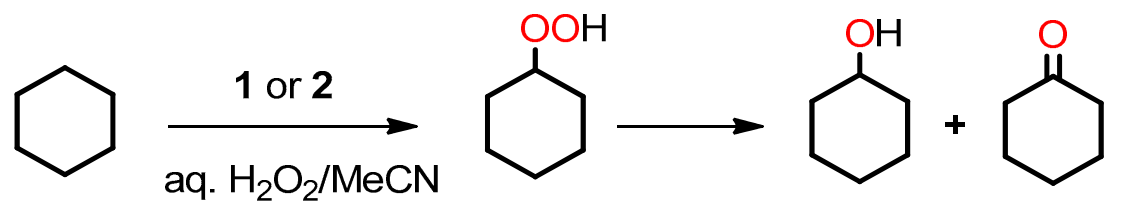

Scheme 3. Oxidation of cyclohexane to cyclohexyl hydroperoxide, cyclohexanol and cyclohexanone. 
The accumulation of oxygenated products (cyclohexanol and cyclohexanone) in the cyclohexane oxidation catalysed by $\mathbf{1}$ and $\mathbf{2}$, in the absence and in the presence of TFA, is given in Table 5 . Both complexes were active for this reaction in the absence of any additive (Figure 5) with approximately 7 and 5\% (for $\mathbf{1}$ and 2, respectively) of total product yield after ca. $0.5 \mathrm{~h}$ (Table 5, entries 3 and 15, for 1 and 2, respectively). Further increase of the reaction time to $2 \mathrm{~h}$ slightly improved the total yield of the products in the presence of $\mathbf{1}$ and almost had not effect when $\mathbf{2}$ was the catalyst. The presence of TFA improved the catalytic performance of both copper compounds, more markedly for 1 with the total yield of cyclohexanol and cyclohexanone achieving ca. 13\% in $1 \mathrm{~h}$ (Table 5, entry 11). The promoting effect of an acid co-catalyst was already observed for other Cu-catalysed systems in the oxidative transformation of alkanes and can be related to (i) its involvement in proton transfer steps, (ii) catalyst activation by unsaturation of the $\mathrm{Cu}$ (II) centres upon ligand protonation or to the (iii) facilitation of the formation of peroxo complexes [27,52-56].

The activity exhibited by compounds 1 and 2, even in the absence of TFA, is higher than that shown, e.g., by $\left[\mathrm{Cu}(\mathrm{OTf})_{2}\left(\mathrm{Py}_{2} \mathrm{~S}_{2}\right)\right]\left(\mathrm{Py}_{2} \mathrm{~S}_{2}=1,6\right.$-bis(2'-pyridyl)-2,5-dithiahexane) (with $4.3 \%$ overall yield) [57] and is comparable to those of the complexes bearing azathia macrocycles, e.g., [Cu(OTf $\left.)_{2}\left(\mathrm{~L}^{3}\right)\right]$ $\left(\mathrm{L}^{3}=\right.$ mixed 14-membered $\mathrm{N}_{2} \mathrm{~S}_{2}$ azathia macrocycle) or $\left[\mathrm{Cu}(\mathrm{OTf})\left(\mathrm{L}^{4}\right)\left(\mathrm{H}_{2} \mathrm{O}\right)\right](\mathrm{OTf})\left(\mathrm{L}^{4}=\right.$ nine-membered $\mathrm{NS}_{2}$ macrocyclic ligand with a 2-methylpyridyl pendant arm) (overall yield of ca. 8\%) [58].

Table 5. Total yield (cyclohexanol and cyclohexanone) with time in the oxidation of cyclohexane by $\mathrm{H}_{2} \mathrm{O}_{2}$ at $50{ }^{\circ} \mathrm{C}$ in $\mathrm{CH}_{3} \mathrm{CN}$ catalysed by 1 or $2^{a}$.

\begin{tabular}{|c|c|c|c|c|c|c|}
\hline \multirow[t]{2}{*}{ Entry } & \multirow[t]{2}{*}{ Precatalyst } & \multirow[t]{2}{*}{ Acid Co-Catalyst } & \multirow[t]{2}{*}{ Reaction Time (min) } & \multicolumn{3}{|c|}{ Yield (\%) } \\
\hline & & & & OL & ONE & Total $^{b}$ \\
\hline 1 & 1 & - & 5 & 3.7 & 3.2 & 6.9 \\
\hline 2 & & - & 15 & 4.1 & 3.6 & 7.7 \\
\hline 3 & & - & 30 & 4.2 & 3.7 & 7.9 \\
\hline 4 & & - & 45 & 4.3 & 3.8 & 8.1 \\
\hline 5 & & - & 60 & 4.5 & 3.8 & 8.3 \\
\hline 6 & & - & 120 & 4.8 & 3.9 & 8.7 \\
\hline 7 & & TFA & 5 & 3.8 & 2.3 & 6.1 \\
\hline 8 & & TFA & 15 & 5.3 & 3.5 & 8.8 \\
\hline 9 & & TFA & 30 & 5.9 & 4.5 & 10.4 \\
\hline 10 & & TFA & 45 & 6.6 & 5.2 & 11.8 \\
\hline 11 & & TFA & 60 & 7.2 & 5.3 & 12.5 \\
\hline 12 & & TFA & 120 & 7.8 & 5.3 & 13.1 \\
\hline 13 & 2 & - & 5 & 3.3 & 1.6 & 4.9 \\
\hline 14 & & - & 15 & 3.5 & 1.7 & 5.2 \\
\hline 15 & & - & 30 & 3.5 & 1.9 & 5.4 \\
\hline 16 & & - & 45 & 3.6 & 1.8 & 5.4 \\
\hline 17 & & - & 60 & 3.7 & 1.8 & 5.5 \\
\hline 18 & & - & 120 & 3.9 & 1.6 & 5.5 \\
\hline 18 & & TFA & 5 & 2.9 & 2.2 & 5.1 \\
\hline 20 & & TFA & 15 & 3.6 & 1.9 & 5.5 \\
\hline 21 & & TFA & 30 & 4.1 & 2.0 & 6.1 \\
\hline 22 & & TFA & 45 & 4.4 & 1.9 & 6.3 \\
\hline 23 & & TFA & 60 & 4.8 & 2.0 & 6.8 \\
\hline 24 & & TFA & 120 & 5.1 & 2.5 & 7.6 \\
\hline
\end{tabular}

${ }^{a}$ Reaction conditions: $\mathrm{C}_{6} \mathrm{H}_{12}(0.46 \mathrm{M}), \mathbf{1}$ or $2\left(5 \times 10^{-4} \mathrm{M}\right)$, TFA $\left(5 \times 10^{-3} \mathrm{M}\right), \mathrm{H}_{2} \mathrm{O}_{2}(50 \%$ aq, $2.2 \mathrm{M}), \mathrm{MeCN}$ (up to $5 \mathrm{~mL}$ total volume), $50{ }^{\circ} \mathrm{C} .{ }^{b}$ Moles of products [cyclohexanol (OL) + cyclohexyl hydroperoxide $(\mathrm{OOH})$ + cyclohexanone (ONE)]/100 mol of $\mathrm{C}_{6} \mathrm{H}_{12}$, determined by GC after treatment with $\mathrm{PPh}_{3} .{ }^{c}$ Moles of products (cyclohexanol + cyclohexanone) per mol of catalyst precursor. 


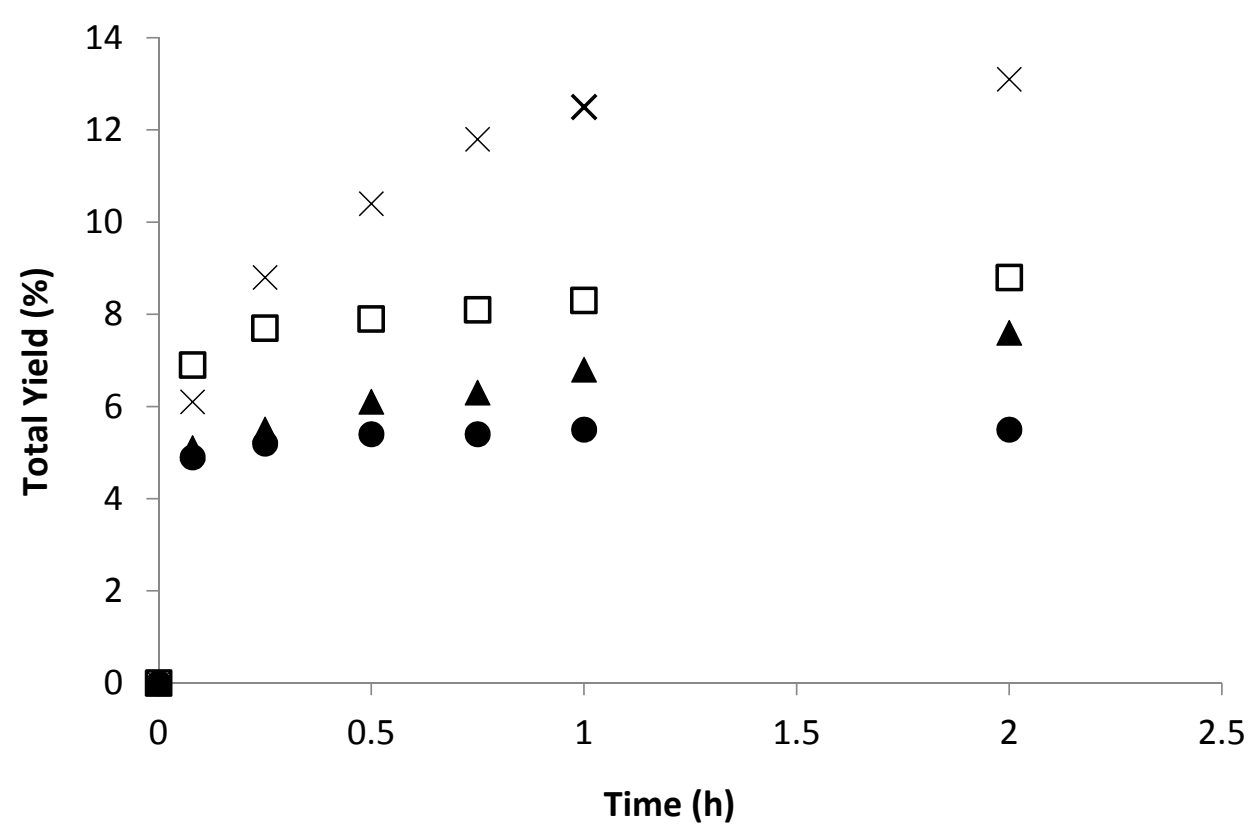

Figure 5. Total yield (cyclohexanol and cyclohexanone) along the time in the oxidation of cyclohexane with aq. $\mathrm{H}_{2} \mathrm{O}_{2}$ catalyzed by 1 in the absence of any additive ( $\square$, squares) or in the presence of TFA $(1: 10)(\times$, cross $)$, or by $\mathbf{2}$ in the absence of any additive $(\bullet$, circles $)$ or in the presence of TFA (1:10) $\left(\boldsymbol{\Lambda}\right.$, triangles), at $50^{\circ} \mathrm{C}$ in $\mathrm{CH}_{3} \mathrm{CN}$.

The formation of cyclohexyl hydroperoxide $\mathrm{CyOOH}$ was confirmed by GC-MS methods and accounts for a free radical reaction mechanism, which conceivably involves the presence of oxygen-centered radicals, $\mathrm{HOO}^{\bullet}$ and $\mathrm{HO} \bullet$, very reactive species, formed upon reaction of the catalyst with hydrogen peroxide (Equations (7) and (8)) [50,59-62] and enhanced by the presence of TEMPO radical. The $\mathrm{HO} \bullet$ radical abstracts hydrogen from cyclohexane $\mathrm{CyH}$ to produce cyclohexyl radical $\mathrm{Cy} \bullet$ (Equation (9)), which is then trapped by dioxygen to give CyOO• radical (Equation (10)). The latter may react with the oxidant to form $\mathrm{CyOOH}$ (Equation (11)). Metal-assisted decomposition of $\mathrm{CyOOH}$ to $\mathrm{CyO} \bullet$ and $\mathrm{CyOO} \bullet$ (Equations (12) and (13)) would then lead to cyclohexanol (CyOH) and cyclohexanone $(\mathrm{Cy}-\mathrm{H}=\mathrm{O})$ products (Equations (14) and (15)) [61].

$$
\begin{gathered}
\mathrm{Cu}(\mathrm{II})+\mathrm{HOOH} \rightarrow \mathrm{HOO} \bullet+\mathrm{H}^{+}+\mathrm{Cu}(\mathrm{I}) \\
\mathrm{Cu}(\mathrm{I})+\mathrm{HOOH} \rightarrow \mathrm{HO} \bullet+\mathrm{Cu}(\mathrm{II})+\mathrm{HO}^{-} \\
\mathrm{HO} \bullet+\mathrm{CyH} \rightarrow \mathrm{ROH}+\mathrm{Cy} \bullet \\
\mathrm{Cy} \bullet+\mathrm{O}_{2} \rightarrow \mathrm{CyOO} \bullet \\
\mathrm{CyOO} \bullet+\mathrm{HOOH} \rightarrow \mathrm{CyOOH}+\mathrm{HOO} \bullet \\
\mathrm{CyOOH}+\mathrm{Cu}(\mathrm{I}) \rightarrow \mathrm{CyO} \bullet+\mathrm{Cu}(\mathrm{II})+\mathrm{HO}^{-} \\
\mathrm{CyOOH}+\mathrm{Cu}(\mathrm{II}) \rightarrow \mathrm{CyOO} \bullet+\mathrm{H}^{+}+\mathrm{Cu}(\mathrm{I}) \\
\mathrm{CyO} \bullet+\mathrm{CyH} \rightarrow \mathrm{CyOH}+\mathrm{Cy} \bullet \\
2 \mathrm{CyOO} \bullet \rightarrow \mathrm{CyOH}+\mathrm{Cy}-\mathrm{H}=\mathrm{O}+\mathrm{O}_{2}
\end{gathered}
$$

The coordination of the oxidant to the metal centre is dependent on the Lewis acidity of the latter. The more Lewis acid metal centre should be easier to reduce. To correlate the electrochemical and catalytic behaviours, the reduction potentials of both complexes were determined by cyclic 
voltammetry (see above). In fact, complex 1, the most active one in both oxidation reactions, is easier to reduce than 2 (reduction at a less negative potential, i.e., ${ }^{\mathrm{I}} E_{\mathrm{p}}{ }^{\text {red }}-0.27 \mathrm{~V}$ versus $-0.43 \mathrm{~V}$ vs. SCE).

\section{Experimental Section}

\subsection{General Materials and Equipment}

All synthetic work was performed in air. Commercially available reagents and solvents were used as received, without further purification or drying. $\mathrm{Cu}\left(\mathrm{NO}_{3}\right)_{2} \cdot 5 \mathrm{H}_{2} \mathrm{O}$ was used as a metal source for the synthesis of the complexes.

$\mathrm{C}, \mathrm{H}$, and $\mathrm{N}$ elemental analyses were carried out by the Microanalytical Service of Instituto Superior Técnico. Infrared spectra $\left(4000-400 \mathrm{~cm}^{-1}\right)$ were recorded on a Bruker Vertex 70 instrument in $\mathrm{KBr}$ pellets; wavenumbers are in $\mathrm{cm}^{-1}$. The ${ }^{1} \mathrm{H}$ NMR spectra were recorded at room temperature on a Bruker Avance II $+400.13 \mathrm{MHz}$ (UltraShieldTM Magnet, Rheinstetten, Germany) spectrometer. Tetramethylsilane was used as the internal reference and the chemical shifts are reported in ppm. Mass spectra were run in a Varian 500-MS LC Ion Trap Mass Spectrometer equipped with an electrospray (ESI) ion source. For electrospray ionization, the drying gas and flow rate were optimized according to the particular sample with 35 p.s.i. nebulizer pressure. Scanning was performed from $\mathrm{m} / \mathrm{z} 100$ to 1200 in methanol solution. The compounds were observed in the positive mode (capillary voltage $=80-105 \mathrm{~V}$ ). The catalytic tests were performed under microwave $(\mathrm{MW})$ irradiation using a focused Anton Paar Monowave 300 microwave fitted with a rotational system and an IR temperature detector, using a $10 \mathrm{~mL}$ capacity reaction tube with a $13 \mathrm{~mm}$ internal diameter. Gas chromatographic (GC) measurements were carried in a FISONS Instrument GC 8000 series gas chromatograph with a capillary DB-WAX column $(30 \mathrm{~m} \times 0.32 \mathrm{~mm})$, a FID detector, helium as the carrier gas and using the Jasco-Borwin v.1.50 software. The magnetic susceptibility measurements were carried out on polycrystalline samples with a Quantum Design MPMS-XL5 SQUID magnetometer in the temperature range of 2-300 K and at an applied field of 2000 Oe. Diamagnetic corrections were estimated from Pascal's constants for all constituent atoms [63]. The electrochemical experiments were performed in an EG\&G PAR 273A potentiostat/galvanostat connected to a personal computer through a GPIB interface.

Syntheses of the pro-ligand $\mathrm{H}_{4} \mathrm{~L}$ : The aroylhydrazone Schiff base pro-ligand bis(2-hydroxybenzylidene) isophthalohydrazide $\left(\mathrm{H}_{4} \mathrm{~L}\right)$ (Scheme 1) was prepared by a reported method $[64,65]$ upon condensation of the 2-hydroxybenzohydrazide with isophthalohydrazide.

Yield: $84 \%$. Anal. Calcd for $\mathrm{H}_{4} \mathrm{~L} \mathrm{C}_{22} \mathrm{H}_{18} \mathrm{~N}_{4} \mathrm{O}_{4}$ : C, 65.66; $\mathrm{H}, 4.51 ; \mathrm{N}, 13.92$. Found: $\mathrm{C}, 65.60 ; \mathrm{H}, 4.48$; $\mathrm{N}$, 13.87. IR (KBr pellet, $\left.\mathrm{cm}^{-1}\right)$ : $3212 v(\mathrm{OH}), 3055 v(\mathrm{NH}), 1653 v(\mathrm{C}=\mathrm{O}) .{ }^{1} \mathrm{H}$ NMR (DMSO-d6, 8$): 12.09$ $(\mathrm{s}, 2 \mathrm{H}, \mathrm{OH}), 11.18(\mathrm{~s}, 2 \mathrm{H}, \mathrm{NH}), 8.09(\mathrm{~s}, 2 \mathrm{H},-\mathrm{CH}=\mathrm{N}), 7.58-6.94\left(\mathrm{~m}, 12 \mathrm{H}, \mathrm{C}_{6} \mathrm{H}_{4}\right)$.

Synthesis of $\left[\mathrm{Cu}_{2}\left(1 \mathrm{\kappa NO}^{2}: 2 \mathrm{kN}^{\prime} \mathrm{O}^{2}-\mathrm{H}_{2} \mathrm{~L}\right)\left(\mathrm{NO}_{3}\right)_{2}\left(\mathrm{H}_{2} \mathrm{O}\right)_{2}\right](\mathbf{1}): 0.402 \mathrm{~g}(1.0 \mathrm{mmol})$ of $\mathrm{H}_{4} \mathrm{~L}$ was suspended in $25 \mathrm{~mL}$ of methanol and $0.525 \mathrm{~g} \mathrm{Cu}\left(\mathrm{NO}_{3}\right)_{2} \cdot 5 \mathrm{H}_{2} \mathrm{O}(2.05 \mathrm{mmol})$ were added. The resultant mixture was stirred at room temperature for $15 \mathrm{~min}$; a dark green solution was obtained. The solution was then filtered and the solvent was allowed to evaporate slowly. After 3-4 days, single crystals suitable for $\mathrm{X}$-ray diffraction were isolated, washed 3 times with cold methanol and dried in open air.

Yield: $0.443 \mathrm{~g}(66 \%$, with respect to $\mathrm{Cu})$. Anal. Calcd for $\mathrm{C}_{22} \mathrm{H}_{20} \mathrm{Cu}_{2} \mathrm{~N}_{6} \mathrm{O}_{12}: \mathrm{C}, 38.43 ; \mathrm{H}, 2.93 ; \mathrm{N}$, 12.22. Found: $\mathrm{C}, 38.36 ; \mathrm{H}, 2.90 ; \mathrm{N}, 12.14$. IR $\left(\mathrm{KBr} ; \mathrm{cm}^{-1}\right): 3448 v(\mathrm{OH}), 1612 \vee(\mathrm{C}=\mathrm{N}), 1250 v(\mathrm{C}-\mathrm{O})$ enolic and $1159 v(\mathrm{~N}-\mathrm{N})$. ESI-MS $(+): m / z 672[\mathrm{M}+\mathrm{H}]^{+}(100 \%)$.

Synthesis of $\left[\mathrm{Cu}_{4}\left(\mu-1 \kappa \mathrm{NO}^{2}: 2 \mathrm{\kappa N}^{\prime} \mathrm{O}^{2}-\mathrm{H}_{2} \mathrm{~L}\right)_{2}\left(\mu-\mathrm{NO}_{3}\right)_{2}\left(\mathrm{H}_{2} \mathrm{O}\right)_{4}\right] \cdot 2 \mathrm{C}_{2} \mathrm{H}_{5} \mathrm{OH}(2)$ : To a $20 \mathrm{~mL}$ acetonitrile solution of $\mathrm{H}_{4} \mathrm{~L}(0.402 \mathrm{~g}, 1.00 \mathrm{mmol})$, a $20 \mathrm{~mL}$ ethanol solution of $\mathrm{Cu}\left(\mathrm{NO}_{3}\right)_{2} \cdot 5 \mathrm{H}_{2} \mathrm{O}(0.525 \mathrm{~g}, 2.05 \mathrm{mmol})$ was added and the reaction mixture was stirred for $20 \mathrm{~min}$ at room temperature. The resultant dark green solution was filtered and the filtrate was kept in open air. Dark green single crystals suitable for X-ray diffraction analysis were isolated after 4 days. Crystals were washed 3 times with cold ethanol and dried in open air. 
Yield: $0.800 \mathrm{~g}(64 \%$, with respect to $\mathrm{Cu})$. Anal. Calcd for $\mathrm{C}_{48} \mathrm{H}_{52} \mathrm{Cu}_{4} \mathrm{~N}_{10} \mathrm{O}_{20}$ (2): C, 42.92; $\mathrm{H}, 3.90$; $\mathrm{N}, 10.43$. Found: C, 42.87; H, 3.84; N, 10.39. IR $\left(\mathrm{KBr} ; \mathrm{cm}^{-1}\right): 3456 v(\mathrm{OH}), 2986 v(\mathrm{NH}), 1609 \vee(\mathrm{C}=\mathrm{O})$, and $1168 v(\mathrm{~N}-\mathrm{N})$. ESI-MS (+): $\mathrm{m} / \mathrm{z} 1158[(\mathrm{M}-2 \mathrm{EtOH})+\mathrm{H}]^{+}(100 \%)$.

\subsection{X-Ray Measurements}

Good quality single crystals suitable for X-ray diffraction of $\mathbf{1}$ and $\mathbf{2}$ were immersed in cryo-oil, mounted in Nylon loops and measured at a temperature of $296 \mathrm{~K}$. Intensity data were collected using a Bruker AXS PHOTON 100 diffractometer with graphite monochromated Mo-K $\alpha(\lambda$ 0.71073) radiation. Data were collected using omega scans of $0.5^{\circ}$ per frame and full spheres of data were obtained. Cell parameters were retrieved using Bruker SMART [66] software and refined using Bruker SAINT [66] on all the observed reflections. Absorption corrections were applied using SADABS [66]. Structures were solved by direct methods by using SIR97 [67] and refined with SHELXL2014 [68]. Calculations were performed using WinGX version 2014.1 [69]. All non-hydrogen atoms were refined anisotropically. The $\mathrm{H}$-atoms bonded to carbons were included in the model at geometrically calculated positions and refined using a riding model. $\mathrm{U}_{\text {iso }}(\mathrm{H})$ values were defined as $1.2 \mathrm{U}_{\text {eq }}$ of the parent aromatic and methylene groups and $1.5 \mathrm{U}_{\mathrm{eq}}$ of the parent methyl ones. The other hydrogen atoms $(\mathrm{O}-\mathrm{H}$ and $\mathrm{N}-\mathrm{H}$ ) were located in the difference Fourier synthesis and refined, in some cases with the help of distance and angle restraints, their isotropic thermal parameter set at 1.5 times the average thermal parameter of the parent oxygen or nitrogen atom. The structure of 1 appears to have three water molecules per unit cell, but their hydrogen atoms could not be ascertained and the Calc-OH routine of WinGX led to unreasonable locations. The possibility of disordered solvent molecules in a void was taken into consideration and Platon/Squeeze [70] was used to establish a void of $158 \AA^{3}$ with 56 electrons; removing such content in the void did not lead to any improved solution, the reason why such strategy was not followed. Least square refinements with anisotropic thermal motion parameters for all the non-hydrogen atoms and isotropic for the remaining atoms were employed.

\subsection{Electrochemical Studies}

Cyclic voltammetry (CV) and controlled-potential electrolyses (CPE) were undertaken in $0.2 \mathrm{M}$ $\left[{ }^{n} \mathrm{Bu}_{4} \mathrm{~N}\right]\left[\mathrm{BF}_{4}\right] / \mathrm{DMSO}$ electrolyte solutions, saturated with $\mathrm{N}_{2}$ before each run, at room temperature. They were performed in a three-electrode cell equipped with a Luggin capillary connected to a silver wire pseudo-reference electrode. Platinum disc (for $\mathrm{CV} ; \mathrm{d}=1 \mathrm{~mm}$ ) or gauze (CPE) working electrodes were used, as well as platinum wire (CV) or gauze (CPE) counter electrodes. In CPE experiments, the working and counter compartments were separated by a sintered glass frit and the studies were monitored regularly by $\mathrm{CV}$. The redox potentials were measured using ferrocene as internal standard, and their values are quoted relative to the SCE by using the $\left[\mathrm{Fe}\left(\eta^{5}-\mathrm{C}_{5} \mathrm{H}_{5}\right)_{2}\right]^{0 /+}$ redox couple $\left(E_{1 / 2}^{\mathrm{OX}}=0.44 \mathrm{~V}\right.$ vs. SCE for DMSO) [71-76].

\subsection{Typical Procedures and Product Analysis for Catalysis}

The microwave-assisted (MW) solvent-free peroxidative catalytic oxidation of 1-phenyethanol was performed in a focused Anton Paar Monowave 300 reactor using a $10 \mathrm{~mL}$ capacity cylindric Pyrex tube with a $13 \mathrm{~mm}$ internal diameter, fitted with a rotational system and an IR temperature detector. The tube was charged with the alcohol $(2.5 \mathrm{mmol}), 5 \mu \mathrm{mol}$ catalyst precursor 1 or $2(0.2 \mathrm{~mol} \% \mathrm{vs}$. substrate) and a $70 \%$ aqueous solution of $t-\mathrm{BuOOH}(5 \mathrm{mmol})$, sealed, placed in the microwave reactor and the system left stirring under irradiation ( 5 or $20 \mathrm{~W}$ ) at 80 or $120^{\circ} \mathrm{C}$ for $0.5-3 \mathrm{~h}$. After cooling to room temperature, $150 \mu \mathrm{L}$ of benzaldehyde (internal standard) and $2.5 \mathrm{~mL}$ of $\mathrm{MeCN}$ (to extract the substrate and the organic products from the reaction mixture) were added. The obtained mixture was stirred for $10 \mathrm{~min}$ and then a sample $(1 \mu \mathrm{L})$ was taken from the organic phase and analysed by GC.

The peroxidative oxidations of cyclohexane were performed in round bottom flasks with vigorous stirring and using $\mathrm{MeCN}$ as solvent (up to $5.0 \mathrm{~mL}$ total volume), under air. The catalyst precursors 1 and $\mathbf{2}$ and trifluoroacetic acid (TFA, optional), in the form of a stock solution in acetonitrile, were mixed, 
cyclohexane $(0.25 \mathrm{~mL}, 2.3 \mathrm{mmol})$ was included and the reaction started when hydrogen peroxide was added $\left(50 \%\right.$ in $\left.\mathrm{H}_{2} \mathrm{O}, 0.68 \mathrm{~mL}, 11 \mathrm{mmol}\right)$. The concentrations of the reactants were thus as follows: catalyst precursor $\left(5 \times 10^{-4} \mathrm{~mol} \mathrm{~L}^{-1}\right)$, TFA $\left(0.005 \mathrm{~mol} \mathrm{~L}^{-1}\right)$, substrate $\left(0.46 \mathrm{~mol} \mathrm{~L}^{-1}\right)$ and $\mathrm{H}_{2} \mathrm{O}_{2}(2.2 \mathrm{~mol}$ $\mathrm{L}^{-1}$ ). The reaction mixture was stirred at $50{ }^{\circ} \mathrm{C}$ for $2 \mathrm{~h}$ and at $5,15,30,45,60$ and $120 \mathrm{~min}$, an aliquot was taken and analysed by GC using nitromethane $(50 \mu \mathrm{L})$ as internal standard. Before the GC analysis an excess of triphenylphosphine was added, in order to reduce the formed cyclohexyl hydroperoxide to the corresponding alcohol and hydrogen peroxide to water, following a method developed by Shul'pin [49-51]. Blank experiments were performed and confirmed that no product of cyclohexane oxidation was obtained unless the metal catalyst was used.

For the GC measurements, the temperature of injection was $240{ }^{\circ} \mathrm{C}$. The initial temperature of the column was maintained at $100{ }^{\circ} \mathrm{C}$ (oxidation of cyclohexane) or $120^{\circ} \mathrm{C}$ (oxidation of alcohol) for $1 \mathrm{~min}$, then raised $10{ }^{\circ} \mathrm{C} / \mathrm{min}$ up to $180{ }^{\circ} \mathrm{C}$ (oxidation of cyclohexane) or $200{ }^{\circ} \mathrm{C}$ (oxidation of alcohol), and held at this temperature for $1 \mathrm{~min}$. Attribution of peaks was made by comparison with chromatograms of genuine samples and, in some cases, by GC-MS analyses using a Perkin Elmer Clarus $600 \mathrm{C}$ instrument (He as the carrier gas), equipped with a $30 \mathrm{~m} \times 0.22 \mathrm{~mm} \times 25 \mu \mathrm{m}$ BPX5 (SGE) capillary column.

\section{Conclusions}

The dinuclear $\left[\mathrm{Cu}_{2}\left(1 \kappa N O^{2}: 2 \kappa N^{\prime} \mathrm{O}^{\prime 2}-\mathrm{H}_{2} \mathrm{~L}\right)\left(\mathrm{NO}_{3}\right)_{2}\left(\mathrm{H}_{2} \mathrm{O}\right)_{2}\right](\mathbf{1})$ and the tetranuclear $\left[\mathrm{Cu}_{4}(\mu-\right.$ $\left.\left.1 \kappa N O^{2}: 2 \kappa N^{\prime} \mathrm{O}^{\prime 2}-\mathrm{HL}\right)_{2}\left(\mu-\mathrm{NO}_{3}\right)_{2}\left(\mathrm{H}_{2} \mathrm{O}\right)_{4}\right]$ (2) complexes derived from bis(2-hydroxybenzylidene) isophthalohydrazide $\left(\mathrm{H}_{4} \mathrm{~L}\right)$ have been synthesized and characterized. The electrochemical studies show two one-electron cathodic reductions $\left[\mathrm{Cu}^{\mathrm{II}} \rightarrow \mathrm{Cu}^{\mathrm{I}}\right.$ and $\left.\mathrm{Cu}^{\mathrm{I}} \rightarrow \mathrm{Cu}^{0}\right]$. The variable temperature magnetic susceptibility measurements of $\mathbf{2}$ show strong antiferromagnetic exchange between the $\mathrm{Cu}$ (II) ions meadiated by the $\mathrm{O}$-phenolate and $\mathrm{NO}_{3}{ }^{-}$bridges.

Both complexes act as catalyst precursors towards the solvent-free microwave-assisted oxidation of alcohols and the peroxidative oxidation of alkanes under mild conditions. The highest activity and selectivity with a maximum product yield of 99\% (for the 1-phenylethanol oxidation after $1 \mathrm{~h}$ without any additive) were observed with $\mathbf{1}$. In the case of oxidation of cyclohexane, $\mathbf{1}$ also exhibits a better activity (a maximum product yield of $13 \%$ after $3 \mathrm{~h}$ ) than 2 .

The catalytic oxidations under microwave assisted and solvent-free conditions have significance for the development of environmentally friendly catalytic systems and deserve further investigations. Our study was an attempt to contribute to this aim.

Supplementary Materials: The following are available online, Cif: Compound 1 and Compound 2. CCDC 1858873 and 1858872 for 1 and 2 contain the supplementary crystallographic data for this paper. This data can be obtained free of charge from The Cambridge Crystallographic Data Centre via www.ccdc.cam.ac.uk/data_request/cif.

Author Contributions: Conceptualization, M.S. and E.C.B.A.A.; Methodology, M.S. and E.C.B.A.A.; Software, M.S., M.F.C.G.d.S. and C.M.L.; Validation, M.S., M.F.C.G.d.S. and C.M.L.; Formal Analysis, M.S. and E.C.B.A.A.; Investigation, M.S.; Resources, M.S. and A.J.L.P.; Data Curation, M.F.C.G.d.S. and C.M.L.; Writing-Original Draft Preparation, M.S. and E.C.B.A.A.; Writing-Review \& Editing, M.F.C.G.d.S., C.M.L.and A.J.L.P.; Visualization, M.S.; Supervision, M.S. and E.C.B.A.A. and M.F.C.G.d.S.; Project Administration, A.J.L.P.; Funding Acquisition, A.J.L.P.

Funding: This research was funded by Fundação para a Ciência e a Tecnologia, Portugal grant number UID/QUI/00100/2013, PTDC/QEQ-ERQ/1648/2014 and PTDC/QEQ-QIN/3967/2014.

Acknowledgments: Authors are grateful to the Fundação para a Ciência e a Tecnologia: FCT (projects UID/QUI/00100/2013, PTDC/QEQ-ERQ/1648/2014 and PTDC/QEQ-QIN/3967/2014), Portugal, for financial support. M.S. acknowledges the FCT, Portugal for a postdoctoral fellowship (SFRH/BPD/86067/2012). Authors are thankful to the Portuguese NMR Network (IST-UL Centre) for access to the NMR facility and the IST Node of the Portuguese Network of mass-spectrometry for the ESI-MS measurements.

Conflicts of Interest: The authors declare no conflict of interest. 


\section{References}

1. Kopylovich, M.N.; Ribeiro, A.P.C.; Alegria, E.C.B.A.; Martins, N.M.R.; Martins, L.M.D.R.S.; Pombeiro, A.J.L. Catalytic oxidation of alcohols: Recent advances. Adv. Organomet. Chem. 2015, 63, 91-174.

2. Karabach, Y.Y.; Kopylovich, M.N.; Mahmudov, K.T.; Pombeiro, A.J.L. Microwave-assisted catalytic oxidation of alcohols to carbonyl compounds. In Advances in Organometallic Chemistry Catalysis; Pombeiro, A.J.L., Ed.; John Wiley \& Sons: Hoboken, NJ, USA, 2014; Chapter 18, pp. 233-245.

3. Mallat, T.; Baiker, A. Oxidation of Alcohols with Molecular Oxygen on Solid Catalysts. Chem. Rev. 2004, 104, 3037-3058. [CrossRef] [PubMed]

4. Allen, S.E.; Walvoord, R.R.; Padilla-Salinas, R.; Kozlowski, M.C. Aerobic copper-catalyzed organic reactions. Chem. Rev. 2013, 113, 6234-6458. [CrossRef] [PubMed]

5. Sheldon, R.A.; Arends, I.W.C.E.; Dijksman, A. New developments in catalytic alcohol oxidations for fine chemicals synthesis. Catal. Today 2000, 57, 157-166. [CrossRef]

6. Ryland, B.L.; Stahl, S.S. Practical aerobic oxidations of alcohols and amines with homogeneous copper/TEMPO and related catalyst systems. Angew. Chem. Int. Ed. Engl. 2014, 53, 8824-8838. [CrossRef] [PubMed]

7. Trincado, M.; Banerjee, D.; Grutzmacher, H. Molecular catalysts for hydrogen production from alcohols. Energy Environ. Sci. 2014, 7, 2464-2503. [CrossRef]

8. Sheldon, R.A.; Arends, I.W.C.E.; Ten Brink, G.J.; Dijksman, A.G. Catalytic Oxidations of Alcohols. Acc. Chem. Res. 2002, 35, 774-781. [CrossRef] [PubMed]

9. Dobereiner, G.E.; Crabtree, R.H. Dehydrogenation as a Substrate-Activating Strategy in Homogeneous Transition-Metal Catalysis. Chem. Rev. 2010, 110, 681-703. [CrossRef] [PubMed]

10. Mizuno, N. Modern Heterogeneous Oxidation Catalysis; Wiley-VCH Verlag GmbH \& Co. KGaA: Weinheim, Germany, 2009.

11. Sheldon, R.A.; Arends, I.W.C.E. Organocatalytic Oxidations Mediated by Nitroxyl Radicals. Adv. Synth. Catal. 2004, 346, 1051-1071. [CrossRef]

12. Sutradhar, M.; Alegria, E.C.B.A.; Barman, T.R.; Scorcelletti, F.; Guedes da Silva, M.F.C.; Pombeiro, A.J.L. Microwave-assisted peroxidative oxidation of toluene and 1-phenylethanol with monomeric keto and polymeric enol aroylhydrazone Cu(II) complexes. Mol. Cat. 2017, 439, 224-232. [CrossRef]

13. Ribeiro, A.P.C.; Fontolan, E.; Alegria, E.C.B.A.; Kopylovich, M.N.; Bertani, R.; Pombeiro, A.J.L. The influence of multiwalled carbon nanotubes and graphene oxide additives on the catalytic activity of $3 \mathrm{~d}$ metal catalysts towards alcohol oxidation. J. Mol. Catal. Chem. 2017, 426, 557-563. [CrossRef]

14. Frija, L.M.T.; Alegria, E.C.B.A.; Sutradhar, M.; Cristiano, M.L.S.; Ismael, A.; Kopylovich, M.N.; Pombeiro, A.J.L. Copper(II) and cobalt(II) tetrazole-saccharinate complexes as effective catalysts for oxidation of secondary alcohols. J. Mol. Cat. Chem. 2016, 425, 283-290. [CrossRef]

15. Timokhin, I.; Pettinari, C.; Marchetti, F.; Pettinari, R.; Condello, F.; Galli, S.; Alegria, E.C.B.A.; Martins, L.M.D.R.S.; Pombeiro, A.J.L. Novel coordination polymers with (pyrazolato)-based tectons: Catalytic activity in the peroxidative oxidation of alcohols and cyclohexane. Cryst. Growth Des. 2015, 15, 2303-2317. [CrossRef]

16. Sutradhar, M.; Martins, L.M.D.R.S.; Guedes da Silva, M.F.C.; Pombeiro, A.J.L. Oxido vanadium complexes with tridentate aroylhydrazone as catalyst precursors for solvent-free microwave-assisted oxidation of alcohol. Appl. Catal. Gen. 2015, 493, 50-57. [CrossRef]

17. Zaltariov, M.F.; Alexandru, M.; Cazacu, M.; Shova, S.; Novitchi, G.; Train, C.; Dobrov, A.; Kirillova, M.V.; Alegria, E.C.B.A.; Pombeiro, A.J.L.; et al. Tetranuclear copper(II) complexes with macrocyclic and open-chain disiloxane ligands as catalyst precursors for hydrocarboxylation and oxidation of alkanes and 1-phenylethanol. Eur. J. Inorg. Chem. 2014, 29, 4946-4956. [CrossRef]

18. Kopylovich, M.N.; Mizar, A.; Silva, M.F.C.G.; MacLeod, T.C.O.; Mahmudov, K.T.; Pombeiro, A.J.L. Template syntheses of copper(II) complexes from arylhydrazones of malononitrile and their catalytic activity towards alcohol oxidations and the nitroaldol reaction: Hydrogen bond-assisted ligand liberation and E/Z isomerisation. Chem. Eur. J. 2013, 19, 588-600. [CrossRef] [PubMed]

19. Hartwig, J.F. Evolution of $\mathrm{C}-\mathrm{H}$ bond functionalization from methane to methodology. J. Am. Chem. Soc. 2016, 138, 2-24. [CrossRef] [PubMed]

20. Ribeiro, A.P.C.; Martins, L.M.D.R.S.; Alegria, E.C.B.A.; Matias, I.A.S.; Duarte, T.A.G.; Pombeiro, A.J.L. Catalytic performance of $\mathrm{Fe}(\mathrm{II})$-scorpionate complexes towards cyclohexane oxidation in organic, ionic liquid and/or supercritical $\mathrm{CO}_{2}$ media: A comparative study. Catalysts 2017, 7, 230. [CrossRef] 
21. Pombeiro, A.J.L. Toward functionalization of alkanes under environmentally benign conditions. In Advances. In Organometallic Chemistry and Catalysis; Pombeiro, A.J.L., Ed.; John Wiley \& Sons: Hoboken, NJ, USA, 2014; Chapter 2, pp. 15-25.

22. Shul'pin, G.B. New trends in oxidative functionalization of carbon-hydrogen bonds: A review. Catalysts 2016, 6, 50. [CrossRef]

23. Shul'pin, G.B. Hydrocarbon oxygenations with peroxides catalyzed by metal compounds. Mini-Rev. Org. Chem. 2009, 6, 95-104. [CrossRef]

24. Shul'pin, G.B. Selectivity enhancement in functionalization of C-H bonds: A review. Org. Biomol. Chem. 2010, 8, 4217-4228. [CrossRef] [PubMed]

25. Martins, L.M.D.R.S.; Pombeiro, A.J.L. Tris(pyrazol-1yl)methane metal complexes for catalytic mild oxidative functionalizations of alkanes, alkenes and ketones. Coord. Chem. Rev. 2014, 265, 74-88. [CrossRef]

26. Martins, L.M.D.R.S.; Pombeiro, A.J.L. Water-soluble C-scorpionate complexes: Catalytic and biological applications. Eur. J. Inorg. Chem. 2016, 2236-2252. [CrossRef]

27. Kirillov, A.M.; Kirillova, M.V.; Pombeiro, A.J.L. Multicopper complexes and coordination polymers for mild oxidative functionalization of alkanes. Coord. Chem. Rev. 2012, 256, 2741-2759. [CrossRef]

28. Buvaylo, E.A.; Kokozay, V.N.; Vassilyeva, O.Y.; Skelton, B.W.; Nesterova, O.V.; Pombeiro, A.J.L. Copper(II) complex of the 2-pyridinecarbaldehyde aminoguanidine Schiff base: Crystal structure and catalytic behaviour in mild oxidation of alkanes. Inorg. Chem. Commun. 2017, 78, 85-90. [CrossRef]

29. Sutradhar, M.; Martins, L.M.D.R.S.; Guedes da Silv, M.F.C.; Pombeiro, A.J.L. Vanadium complexes: Recent progress in oxidation catalysis. Coord. Chem. Rev. 2015, 301-302, 200-239. [CrossRef]

30. Sutradhar, M.; Kirillova, M.V.; Guedes da Silva, M.F.C.; Martins, L.M.D.R.S.; Pombeiro, A.J.L. A hexanuclear oxovanadium $(\mathrm{IV}, \mathrm{V})$ complex bearing $\mathrm{N}, \mathrm{O}$-ligand as a highly efficient alkane oxidation catalyst. Inorg. Chem. 2012, 51, 11229-11231. [CrossRef] [PubMed]

31. Sutradhar, M.; Martins, L.M.D.R.S.; Guedes da Silva, M.F.C.; Alegria, E.C.B.A.; Liu, C.M.; Pombeiro, A.J.L. $\mathrm{Mn}(\mathrm{II}, \mathrm{II})$ complexes: Magnetic properties and microwave assisted oxidation of alcohols. Dalton. Trans. 2014, 43, 3966-3977. [CrossRef] [PubMed]

32. Sutradhar, M.; Martins, L.M.D.R.S.; Guedes da Silva, M.F.C.; Liu, C.M.; Pombeiro, A.J.L. Trinuclear Cu(II) structural isomers: Coordination, magnetism, electrochemistry and catalytic activity toward oxidation of alkanes. Eur. J. Inorg. Chem. 2015, 3959-3969. [CrossRef]

33. Sutradhar, M.; Alegria, E.C.B.A.; Guedes da Silva, M.F.C.; Martins, L.M.D.R.S.; Pombeiro, A.J.L. Aroylhydrazone $\mathrm{Cu}(\mathrm{II})$ complexes in keto form: Structural characterization and catalytic activity towards cyclohexane oxidation. Molecules 2016, 21, 425. [CrossRef] [PubMed]

34. Sutradhar, M.; Alegria, E.C.B.A.; Mahmudov, K.T.; Guedes da Silva, M.F.C.; Pombeiro, A.J.L. Iron(III) and cobalt(III) complexes with both tautomeric (keto and enol) forms of aroylhydrazone ligands: Catalysts for the microwave assisted oxidation of alcohols. RSC Adv. 2016, 6, 8079-8088. [CrossRef]

35. Chiari, B.; Piovesana, O.; Tarantelli, T.; Zanazzi, P.F. Further neighbor magnetic exchange interaction in a novel pseudolinear tetramer of copper (II). Inorg. Chem. 1993, 32, 4834-4838. [CrossRef]

36. Karabach, Y.Y.; Kopylovich, M.N.; Mahmudov, K.T.; Pombeiro, A.J.L. Microwave-assisted Catalytic oxidation of Alcohols to carbonyl compounds. In Advances in Organometallic Chemistry and Catalysis; Pombeiro, A.J.L., Ed.; Wiley-VCH: Weinheim, Germany; Hoboken, NJ, USA, 2013; Chapter 22, pp. 285-294.

37. Figiel, P.J.; Kopylovich, M.N.; Lasri, J.; Guedes da Silva, M.F.C.; Fraústo da Silva, J.J.R.; Pombeiro, A.J.L. Solvent-free microwave-assisted peroxidative oxidation of secondary alcohols to the corresponding ketones catalyzed by copper (II) 2,4-alkoxy-1,3,5-triazapentadienato complexes. Chem. Commun. 2010, 46, 2766-2768. [CrossRef] [PubMed]

38. Figiel, P.J.; Kirillov, A.M.; Guedes da Silva, M.F.C.; Lasri, J.; Pombeiro, A.J.L. Self-assembled dicopper(II) diethanolaminate cores for mild aerobic and peroxidative oxidation of alcohols. Dalton Trans. 2010, 39, 9879-9888. [CrossRef] [PubMed]

39. Lasri, J.; Rodriguez, M.J.F.; Guedes da Silva, M.F.C.; Smolenski, P.; Kopylovich, M.N.; Fraústo da Silva, J.J.R.; Pombeiro, A.J.L. Microwave synthesis of bis(tetrazolato)-Pd ${ }^{\mathrm{II}}$ complexes with $\mathrm{PPh}_{3}$ and water-soluble 1,3,5-triaza-7-phosphaadamantane (PTA). The first example of $\mathrm{C}-\mathrm{CN}$ bond cleavage of propionitrile by a Pd ${ }^{\mathrm{II}}$ centre. J. Organomet. Chem. 2011, 696, 3513-3520. [CrossRef] 
40. Alexandru, M.; Cazacu, M.; Arvinte, A.; Shova, S.; Turta, C.; Simionescu, B.C.; Dobrov, A.; Alegria, E.C.B.A.; Martins, L.M.D.R.S.; Pombeiro, A.J.L.; et al. $\mu$-Chlorido-bridged dimanganese(II) complexes of the Schiff base derived from [2+2]condensation of 2,6-diformyl-4-methylphenol and 1,3-bis(3-aminopropyl)tetramethyldisiloxane: Structure, magnetism, electrochemical behaviour and catalytic oxidation of secondary alcohols. Eur. J. Inorg. Chem. 2014, 120-131. [CrossRef]

41. Ahmad, J.U.; Figiel, P.J.; Räisänen, M.T.; Leskelä, M.; Repo, T. Aerobic oxidation of benzylic alcohols with bis(3,5-di-tert-butylsalicylaldimine) copper (II) complexes. Appl. Catal. A 2009, 371, 17-21. [CrossRef]

42. Figiel, P.J.; Kirillov, A.M.; Karabach, Y.Y.; Kopylovich, M.N.; Pombeiro, A.J.L. Mild aerobic oxidation of benzyl alcohols to benzaldehydes in water catalyzed by aqua-soluble multicopper(II) triethanolaminate compounds. J. Mol. Catal. Chem. 2009, 305, 178-182. [CrossRef]

43. Martins, N.M.R.; Mahmudov, K.T.; Guedes da Silva, M.F.C.; Martins, L.M.D.R.S.; Pombeiro, A.J.L. Copper(II) and iron(III) complexes with arylhydrazone of ethyl 2-cyanoacetate or formazan ligands as catalysts for oxidation of alcohols. New J. Chem. 2016, 40, 10071-10083. [CrossRef]

44. Sheldon, R.A. E factors, green chemistry and catalysis: An odyssey. Chem. Commun. 2008, 29, 3352-3365. [CrossRef] [PubMed]

45. Michel, C.; Belanzon, P.; Gamez, P.; Reedijk, J.; Baerends, E.J. Activation of the C-H bond by electrophilic attack: Theoretical study of the reaction mechanism of the aerobic oxidation of alcohols to aldehydes by the $\mathrm{Cu}$ (bipy) $)^{2+}$ /2,2,6,6-tetramethylpiperidinyl-1-oxy cocatalyst system. Inorg. Chem. 2009, 48, 11909-11920. [CrossRef] [PubMed]

46. Gamez, P.; Arends, I.W.C.E.; Sheldon, R.A.; Reedijk, J. Room temperature aerobic copper-catalysed selective oxidation of primary alcohols to aldehydes. Adv. Synth. Catal. 2004, 346, 805-811. [CrossRef]

47. Gamez, P.; Arends, I.W.C.E.; Reedijk, J.; Sheldon, R.A. Copper(II)-catalysed aerobic oxidation of primary alcohols to aldehydes. Chem. Commun. 2003, 19, 2414-2415. [CrossRef]

48. Kopylovich, M.N.; Karabach, Y.Y.; Guedes da Silva, M.F.C.; Figiel, P.J.; Lasri, J.; Pombeiro, A.J.L. Alkoxy-1,3,5triazapentadien(e/ato) copper(II) complexes: Template formation and applications for the preparation of pyrimidines and as catalysts for oxidation of alcohols to carbonyl products. Chem. Eur. J. 2012, 18, 899-914. [CrossRef] [PubMed]

49. Shul'pin, G.B. Metal-catalysed hydrocarbon oxygenations in solutions: The dramatic role of additives: A review. J. Mol. Catal. A Chem. 2002, 189, 39-66. [CrossRef]

50. Shul'pin, G.B. Metal-catalysed hydrocarbon oxidations. C. R. Chim. 2003, 6, 163-178. [CrossRef]

51. Shul'pin, G.B.; Kozlov, Y.N.; Shul'pina, L.S.; Kudinov, A.R.; Mandelli, D. Extremely efficient alkane oxidation by a new catalytic reagent $\mathrm{H}_{2} \mathrm{O}_{2} / \mathrm{Os}_{3}(\mathrm{CO})_{12}$ /Pyridine. Inorg. Chem. 2009, 48, 10480-10482. [CrossRef] [PubMed]

52. Kopylovich, M.N.; Nunes, A.C.C.; Mahmudov, K.T.; Haukka, M.; Mac Leod, T.C.O.; Martins, L.M.D.R.S.; Kuznetsov, M.L.; Pombeiro, A.J.L. Complexes of copper(II) with 3-(ortho-substituted phenylhydrazo) pentane-2,4-diones: Syntheses, properties and catalytic activity for cyclohexane oxidation. Dalton Trans. 2011, 40, 2822-2836. [CrossRef] [PubMed]

53. Kirillova, M.V.; Kozlov, Y.N.; Shul'pina, L.S.; Lyakin, Q.Y.; Kirillov, A.M.; Talsi, E.P.; Pombeiro, A.J.L.; Shul'pin, G.B. Remarkably fast oxidation of alkanes by hydrogen peroxide catalyzed by a tetracopper(II) triethanolaminate complex: Promoting effects of acid co-catalysts and water, kinetic and mechanistic features. J. Catal. 2009, 268, 26-38. [CrossRef]

54. Gruenwald, K.R.; Kirillov, A.M.; Haukka, M.; Sanchiz, J.; Pombeiro, A.J.L. Mono-, di- and polynuclear copper(II) compounds derived from N-butyldiethanolamine: Structural features, magnetism and catalytic activity for the mild peroxidative oxidation of cyclohexane. Dalton Trans. 2009, 2109-2120. [CrossRef] [PubMed]

55. Karabach, Y.Y.; Kirillov, A.M.; Haukka, M.; Kopylovich, M.N.; Pombeiro, A.J.L. Copper(II) coordination polymers derived from triethanolamine and pyromellitic acid for bioinspired mild peroxidative oxidation of cyclohexane. J. Inorg. Biochem. 2008, 102, 1190-1194. [CrossRef] [PubMed]

56. Di Nicola, C.; Karabach, Y.Y.; Kirillov, A.M.; Monari, M.; Pandolfo, L.; Pettinari, C.; Pombeiro, A.J.L. Supramolecular assemblies of trinuclear triangular copper(II) secondary building units through hydrogen bonds. Generation of different metal-organic frameworks, valuable catalysts for peroxidative oxidation of alkanes. Inorg. Chem. 2007, 46, 221-230. [CrossRef] [PubMed] 
57. Fernandes, R.R.; Lasri, J.; Guedes da Silva, M.F.C.; da Silva, J.A.L.; Fraústo da Silva, J.J.R.; Pombeiro, A.J.L. Mild alkane $\mathrm{C}-\mathrm{H}$ and $\mathrm{O}-\mathrm{H}$ oxidations catalysed by mixed-N,S copper, iron and vanadium systems. Appl. Catal. Gen. 2011, 402, 110-120. [CrossRef]

58. Fernandes, R.R.; Lasri, J.; Kirillov, A.M.; Guedes da Silva, M.F.C.; da Silva, J.A.L.; Fraústo da Silva, J.J.R.; Pombeiro, A.J.L. New Fe ${ }^{\mathrm{II}}$ and $\mathrm{Cu}^{\mathrm{II}}$ complexes bearing azathia macrocycles-Catalyst precursors for mild peroxidative oxidation of cyclohexane and 1-phenylethanol. Eur. J. Inorg. Chem. 2011, 3781-3790. [CrossRef]

59. Shul'pin, G.B.; Kozlov, Y.N.; Nizova, G.V.; Suss-Frank, G.; Stanislas, S.; Kitaygorodskiy, A.; Kulikova, V.S. Oxidations by the reagent " $\mathrm{O}_{2}-\mathrm{H}_{2} \mathrm{O}_{2}$-vanadium derivative-pyrazine-2-carboxylic acid". Part $12 .{ }^{1}$ Main features, kinetics and mechanism of alkane hydroperoxidation. J. Chem. Soc. Perkin Trans. 2001, 2, 1351-1371. [CrossRef]

60. Kuznetsov, M.L.; Pombeiro, A.J.L. Radical formation in the $\left[\mathrm{MeReO}_{3}\right]$-catalyzed aqueous peroxidative oxidation of alkanes: A theoretical mechanistic study. Inorg. Chem. 2009, 48, 307-318. [CrossRef] [PubMed]

61. Kirilova, M.V.; Kuznetsov, M.L.; Kozlov, Y.N.; Shul'pina, L.S.; Kitaygorodskiy, A.; Pombeiro, A.J.L.; Shul'pin, G.B. Participation of oligovanadates in alkane oxidation with $\mathrm{H}_{2} \mathrm{O}_{2}$ catalyzed by vanadate anion in acidified acetonitrile: Kinetic and DFT studies. ACS Catal. 2011, 1, 1511-1520. [CrossRef]

62. Kirilova, M.V.; Kuznetsov, M.L.; Romakh, V.B.; Shul'pina, L.S.; Fraústo da Silva, J.J.R.; Pombeiro, A.J.L.; Shul'pin, G.B. Mechanism of oxidations with $\mathrm{H}_{2} \mathrm{O}_{2}$ catalyzed by vanadate anion or oxovanadium(V) triethanolaminate (vanadatrane) in combination with pyrazine-2-carboxylic acid (PCA): Kinetic and DFT studies. J. Catal. 2009, 267, 140-157. [CrossRef]

63. Kahn, O. Molecular Magnetism; VCH: New York, NY, USA, 1993.

64. Sutradhar, M.; Mukherjee, G.; Drew, M.G.B.; Ghosh, S. Simple general method of generating non-oxo, non-amavadine model octacoordinated vanadium(IV) complexes of some tetradentate ONNO chelating ligands from various oxovanadium(IV/V) compounds and structural characterization of one of them. Inorg. Chem. 2007, 46, 5069-5075. [CrossRef] [PubMed]

65. Sutradhar, M.; Roy Barman, T.; Mukherjee, G.; Drew, M.G.B.; Ghosh, S. Oxidoalkoxidovanadium(V) complexes: Synthesis, characterization and comparison of X-ray crystal structures. Polyhedron 2012, 34, 92-101. [CrossRef]

66. Bruker. APEX2 \& SAINT; AXS Inc.: Madison, WI, USA, 2004.

67. Altomare, A.; Burla, M.C.; Camalli, M.; Cascarano, G.L.; Giacovazzo, C.; Guagliardi, A.; Moliterni, A.G.G.; Polidori, G.; Spagna, R. SIR97: A new tool for crystal structure determination and refinement. J. Appl. Cryst. 1999, 32, 115-119. [CrossRef]

68. Sheldrick, G.M. A short history of SHELX. Acta Crystallogr. Sect. A 2008, 64, 112-122. [CrossRef] [PubMed]

69. Farrugia, L.J. WinGX and ORTEP for Windows: An update. J. Appl. Cryst. 2012, 45, 849-854. [CrossRef]

70. Spek, A.L. PLATON SQUEEZE: A tool for the calculation of the disordered solvent contribution to the calculated structure factors. Acta Crystall. Sect. C 2015, 71, 9-18. [CrossRef] [PubMed]

71. Guedes da Silva, M.F.C.; Pombeiro, A.J.L. Redox potential parameterization in coordination compounds with polydentate scorpionate and benzene ligands. Electrochim. Acta 2012, 82, 478-483. [CrossRef]

72. Pombeiro, A.J.L.; Guedes da Silva, M.F.C.; Lemos, M.A.N.D.A. Electron-transfer induced isomerizations of coordination compounds. Coord. Chem. Rev. 2001, 219, 53-80. [CrossRef]

73. Silva, M.E.N.P.R.A.; Pombeiro, A.J.L.; Fraústo da Silva, J.J.R.; Herrmann, R.; Deus, N.; Castilho, T.J.; Guedes da Silva, M.F.C. Redox potential and substituent effects at ferrocene derivatives. Estimates of Hammett $\sigma p$ and Taft polar $\sigma$ substituent constants. J. Organomet. Chem. 1991, 421, 75-90.

74. Silva, M.E.N.P.R.A.; Pombeiro, A.J.L.; Fraústo da Silva, J.J.R.; Herrmann, R.; Deus, N.; Bozak, R.E. Redox potential and substituent effects in ferrocene derivatives: II. J. Organomet. Chem. 1994, 480, 81-90. [CrossRef]

75. Pombeiro, A.J.L. Characterization of coordination compounds by electrochemical parameters. Eur. J. Inorg. Chem. 2007, 1473-1482. [CrossRef]

76. Pombeiro, A.J.L. Electron-donor/acceptor properties of carbynes, carbenes, vinylidenes, allenylidenes and alkynyls as measured by electrochemical ligand parameters. J. Organomet. Chem. 2005, 690, 6021-6040. [CrossRef]

(C) 2018 by the authors. Licensee MDPI, Basel, Switzerland. This article is an open access article distributed under the terms and conditions of the Creative Commons Attribution (CC BY) license (http://creativecommons.org/licenses/by/4.0/). 